\title{
A Phalarodon fraasi (Ichthyosauria: Mixosauridae) from the Middle Triassic of Svalbard
}

\author{
Inghild H. Økland', Lene L. Delsett ${ }^{1}$, Aubrey J. Roberts ${ }^{1,2}$ \& Jørn H. Hurum ${ }^{1}$ \\ ${ }^{1}$ Natural History Museum, University of Oslo, P.O. Box 1172 Blindern, N-0318 Oslo, Norway. \\ ${ }^{2}$ The Natural History Museum, Earth Sciences, Cromwell Road, London SW7 5BD, UK. \\ E-mail corresponding author (Jørn H. Hurum): j.h.hurum@nhm.uio.no
}

A new specimen of Phalarodon from the Middle Triassic Botneheia Formation on Svalbard, although not complete, is well preserved with both cranial and postcranial elements. Uncompressed preservation of the rostrum reveals the dental groove divided by alveolar bone between the teeth. The right opisthotic has a thin and plate-like paroccipital process, a structure which has only been observed in Mixosaurus cornalianus among mixosaurids. The rare preservation of the atlas-axis complex, being nearly complete and articulated, is very similar to that of Phalarodon callawayi. The interclavicle, although not complete, is preserved with detailed structures which have previously not been described in Mixosauridae. Contrary to earlier studies, the shoulder girdle, with an articulated scapula and coracoid, reveals a coracoid facet on the scapula. Using comparative morphological and phylogenetic analyses, similarities between the new specimen and the known species of Mixosauridae are addressed. We assign the new specimen to Phalarodon fraasi. With its uncompressed preservation, the new specimen contributes to the knowledge of our morphology of the species. This study suggests a reassignment of the specimen PMO 219.250 to the genus Mixosaurus, and opens up for the possibility of Mixosaurus on Svalbard. This would imply a wider geographical distribution of the genus than previously recognised. Additionally, it would prove the coexistence of Mixosaurus and Phalarodon in a shared habitat at the same point in time, a hypothesis that is strengthened by the differences in dentition which reflects separate feeding habits, and thus different niches.

Keywords: Mixosauridae, Phalarodon, Mixosaurus, P. fraasi, Triassic, Botneheia, Svalbard, Spitsbergen

Electronic Supplement 1: Phylogenetic analysis

Electronic Supplement 2: Ichthyopterygia_analysis1_first_run

Electronic Supplement 3: Ichthyopterygia_analysis1_second_run

Electronic Supplement 4: Ichthyopterygia_analysis2

Received 23. November 2017 / Accepted 21. August 2018 / Published online 4. October 2018

\section{Introduction}

The mixosaurids are a clade of Middle Triassic ichthyosaurs, with a wide distribution (Nicholls et al., 1999; Schmitz et al., 2004; Ji et al., 2015). Their remains have been found in localities on Svalbard (Hulke, 1873; Wiman, 1910; Mazin, 1984; Hurum et al., 2014), in Nevada (Sander \& Bucher, 1990; Schmitz et al., 2004), British Columbia (Callaway \& Brinkman, 1989; Callaway, 1997; Nicholls et al., 1999), Monte San Giorgio (Brinkmann, 1998a, b; Maisch et al., 2006), the Muschelkalk of the Germanic Basin (Maisch \& Matzke, 2001b), Timor,
Turkey and Russia (Mazin, 1983), and China (Jiang et al., 2005, 2008; Liu et al., 2013). An important feature of the mixosaurids is their specialised heterodont dentition (Maisch \& Matzke, 2001b; Jiang et al., 2003; McGowan \& Motani, 2003; Brinkmann, 2004; Schmitz et al., 2004; Liu et al., 2013). The ingroup taxonomy and nomenclature of the mixosaurids has been heavily debated since their initial description (Hulke, 1873; Dames, 1895; Wiman, 1910; Merriam, 1911; Kuhn, 1934; Cox \& Smith, 1973; Callaway \& Brinkman, 1989; Motani, 1999a; Nicholls et al., 1999; Maisch \& Matzke, 2000; Schmitz et al., 2004; Schmitz, 2005; Jiang et al., 2006).

Økland, I.H., Delsett, L.L., Roberts, A.J. \& Hurum, J.H. 2018: A Phalarodon fraasi (Ichthyosauria: Mixosauridae) from the Middle Triassic of Svalbard. Norwegian Journal of Geology 98, 267-288. https://dx.doi.org/10.17850/njg98-2-06. 
The Swedish expeditions to Spitsbergen in 1864 and 1868 , in which ichthyopterygian ribs, vertebrae and jaw fragments were collected, resulted in the description of two new species of ichthyosaurs by Hulke (1873): Ichthyosaurus nordenskioldii, based on the remains of caudal and thoracic vertebrae, and Ichthyosaurus polaris. Baur (1887) established the family Mixosauridae and the genus Mixosaurus. The similarities between $I$. nordenskioldii and Mixosaurus led to the reassignment of this species to Mixosaurus nordenskioldii (Dames, 1895). New expeditions to Spitsbergen by DeGeer in 1908 and Högblom in 1909 provided new material described by Wiman (1910), with both cranial and postcranial remains of $M$. nordenskioldii. Another study published the same year established the genus Phalarodon and the species Phalarodon fraasi based on the skull and dentition of two specimens from Nevada (Merriam, 1910). The dentition of $M$. nordenskioldii was observed to be fairly similar to the dentition of Phalarodon from Nevada (Merriam, 1911; Wiman, 1916).

A specimen from the Middle Triassic of Wapiti Lake, British Columbia, had skull and teeth that resembled Phalarodon but a postcranial skeleton more similar to Mixosaurus (Nicholls et al., 1999). It was assigned to Phalarodon, indicating a great resemblance in postcranial skeleton between the genera, but a significant discrepancy in skull and dental features, confirming the conclusions of a comparative study of skull morphology published the same year (Motani, 1999a). Two mixosaurid specimens from Nevada were described by Schmitz et al. (2004) and assigned to Mixosaurus nordenskioldii and the new species Mixosaurus callawayi. Several specimens previously referred to $M$. nordenskioldii were reassigned to $M$. callawayi based on proportional differences of the vertebral centra, and also osteological differences. After the study by Schmitz (2005), P. fraasi has been considered a valid species, in which Mixosaurus nordenskioldii is considered nomen dubium and thus a junior synonym. With the phylogenetic study by Jiang et al. (2006), including new material from China, a consensus on the validity of both Phalarodon and Mixosaurus inside Mixosauridae was established (Jiang et al., 2006; Kelley et al., 2012; Liu et al., 2013; Ji et al., 2015). Jiang et al. (2006) recognised three species of Mixosaurus; the newly established $M$. panxianensis, $M$. cornalianus and M. kuhnschnyderi, and three species of Phalarodon; $P$. fraasi, $P$. callawayi and $P$. atavus. $P$. atavus (previously Contectopalatus atavus) was placed as a sister taxon to the remaining two species of Phalarodon.The phylogenetic study of Ji et al. (2015) reaffirmed the validity of both Phalarodon and Mixosaurus and their species as in Jiang et al. (2006).

Svalbard is rich in Triassic marine reptile remains, providing material for studies for more than 150 years, in which there has been a significant contribution to our knowledge of the Mixosauridae (Hulke, 1873; Wiman, 1910; Cox \& Smith, 1973; Maxwell \& Kear, 2013; Hurum et al., 2014). Although an abundance of Phalarodon specimens have been recovered from Svalbard, the presence of Mixosaurus has never been confirmed (Maxwell \& Kear, 2013). A Late Ladinian mixosaurid specimen (PMO 219.250) from the Blanknuten Member, Botneheia Formation on Edgeøya, was described by Hurum et al. (2014). The specimen displayed traits from all known species of Mixosauridae, and as such an assignment to a species could not be made, although an affinity to Phalarodon was emphasised.

This study encompasses two mixosaurid specimens from the Middle Triassic of Svalbard; a description of specimen PMO 210.122 from Botneheia, Spitsbergen, and a new analysis of specimen PMO 219.250 from Edgeøya (Hurum et al., 2014). The study seeks to deepen our knowledge of the Mixosauridae fauna on Svalbard, and attempts to assign both specimens to their proper place in the taxonomy. Due to their good preservation and detailed structures, the specimens holds significance for the study of mixosaurids, and cast light on the need for a critical review of the diagnostic traits of Phalarodon.

\section{Geological setting}

The geology of Svalbard (Fig. 1) reflects the regional depositional environment of the Barents Sea Continental Shelf. A main sediment supply from the west in the Triassic resulted in a coastal to basinal depositional environment (Vigran et al., 2014). As such, the Middle Triassic sequences of Western Spitsbergen are characterised by the coastal and shallow-marine sandstones and shales, while Central and Eastern Spitsbergen, Edgeøya and Barentsøya consist of shales and siltstones from a deeper basin (Mørk et al., 1999; Hounslow et al., 2008). The Sassendalen Group was defined by Buchan et al. (1965) and encompasses the Early and Middle Triassic sequences of Svalbard (Hounslow et al., 2008). In Central and Eastern Spitsbergen, as well as Edgeøya, the Sassendalen Group consists of the Vikinghøgda Formation at its base, with the overlying Botneheia Formation (Lundschien et al., 2014; Vigran et al., 2014). Three units of coarseningupward sequences with sharp boundaries can be traced throughout the Sassendalen Group, two of which correspond to the division of the Vikinghøgda Fm., while the last sequence corresponds to the Botneheia Fm. (Mørk et al., 1982). These units represent major coastal progradations, in which the dominant sediment influx came from the west (Hounslow et al., 2008; Vigran et al., 2014). The Vikinghøgda Fm. was a shallow-marine shelf environment with storm deposits, situated east of the deltaic coast environment represented by the sequences of Western Spitsbergen (Mørk et al., 1999; Vigran et al., 2014). A possible transgression event marks the boundary between the Vikinghøgda and Botneheia 

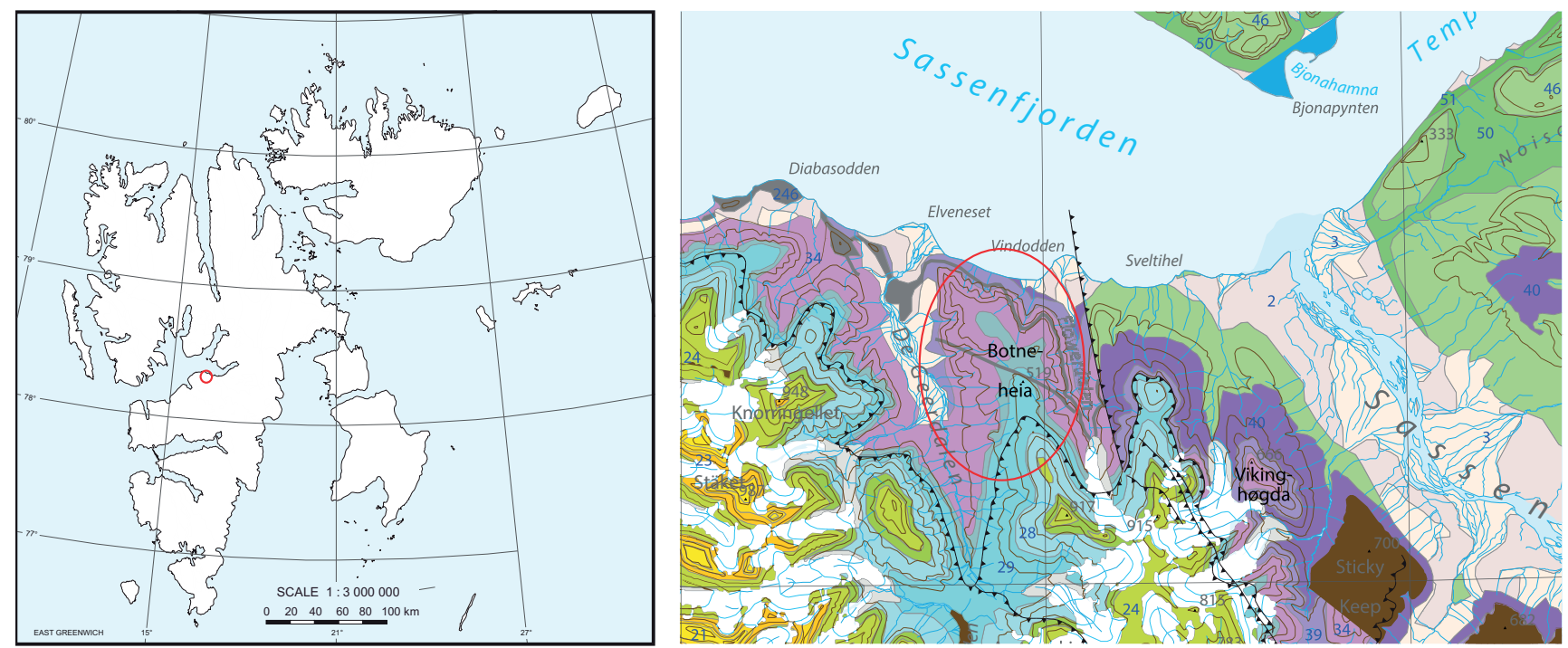

A $\bigcirc$ Botneheia

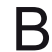

\begin{tabular}{|l|l}
\hline 2 & Marine deposit \\
\cline { 1 - 1 } 3 & Glaci-fluvial deposits \\
\cline { 1 - 1 } 21 & Grumantbyen FM \\
\cline { 1 - 1 } 23 & FirkantenFM \\
\cline { 1 - 1 } 24 & Carolinefjellet FM \\
\cline { 1 - 1 } 28 & Rurikfjellet FM \\
\cline { 1 - 1 } 29 & Agardhfjellet FM \\
\cline { 1 - 1 } 34 & Storfjorden Subgroup
\end{tabular}

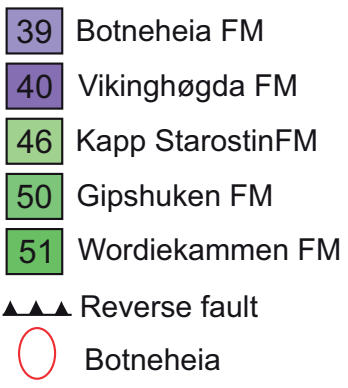

Figure 1. (A) Map of Svalbard. Red circle: Location of Botneheia. (B) Stratigraphic map of Sassenfjorden with legend. The red circle marks Botneheia with the Botneheia Formation, from which PMO 210.122 was collected. Modified from Dallmann (2015).

formations, and the upper sequence of the Botneheia Fm. represents a moderately deep shelf environment, with distal deltaic lobes (Vigran et al., 2014).

Ammonoid faunas, palynoflora, fish and vertebrate fossils are found sporadically throughout the Sassendalen Group (Wiman, 1910, 1916; Stensiö, 1921; Cox \& Smith, 1973; Weitschat \& Lehmann, 1983; Hounslow et al., 2008; Vigran et al., 2014). The Botneheia Formation (Figs. 1B, 2 ) is divided into the Anisian Muen Member and the Ladinian Blanknuten Member (Krajewski, 2008; Vigran et al., 2014). Dark, organic-rich shales with an abundance of phosphate nodules, infracted by alternating layers of bioturbation, characterise the Botneheia Fm. (Lundschien et al., 2014; Vigran et al., 2014). As such, the depositional environment was mainly anoxic in which there were short oxic periods, in a moderate deep shelf environment (Vigran et al., 2014). An ammonoid zonation of the section has been produced (Weitschat \& Lehmann, 1983), correlated to the recent palynozonation (fig. 3a in Vigran et al., 2014): Indigirites tozeri - Upper Ladinian; Tsvetkovites varius - Lower Ladinian; Frechites laqueatus - Upper Anisian.

\section{Material and methods}

PMO 210.122 is housed in the collection of Natural History Museum, University of Oslo, Norway. Both the cranial and the postcranial skeleton are partially preserved. PMO 210.122 was collected from the Blanknuten Member. The section is characterised by black shale and siltstone deposits with carbonate cementation, and an abundance of Daonella (Weitschat \& Lehmann, 1983; Vigran et al., 2014). The collector of the specimen, Wolfgang Weitschat (note on label from 1984), assigned PMO 210.122 to the Upper Ptychitid Layer, Indigirites tozeri-zone (Fig. 2), based on the phosphatic ammonoid Aristoptychites kolymensis that was collected from the same layer as PMO 210.122. The specimen is embedded in Daonella Shales. The specimen is distributed between eight slabs (Fig. 3, Table 1), of which slabs $1 \mathrm{a}$ and $1 \mathrm{~b}$ came from one piece that was separated during preparation. Slab 2 is the counterslab of slab 1a. The bone elements at one margin of slab 3 articulate with elements at the margin of slab $1 \mathrm{a}$. The bone elements at the opposite margin of slab 3 articulate with elements of slab 4 . The remaining slabs, 5, 6 and 7, 


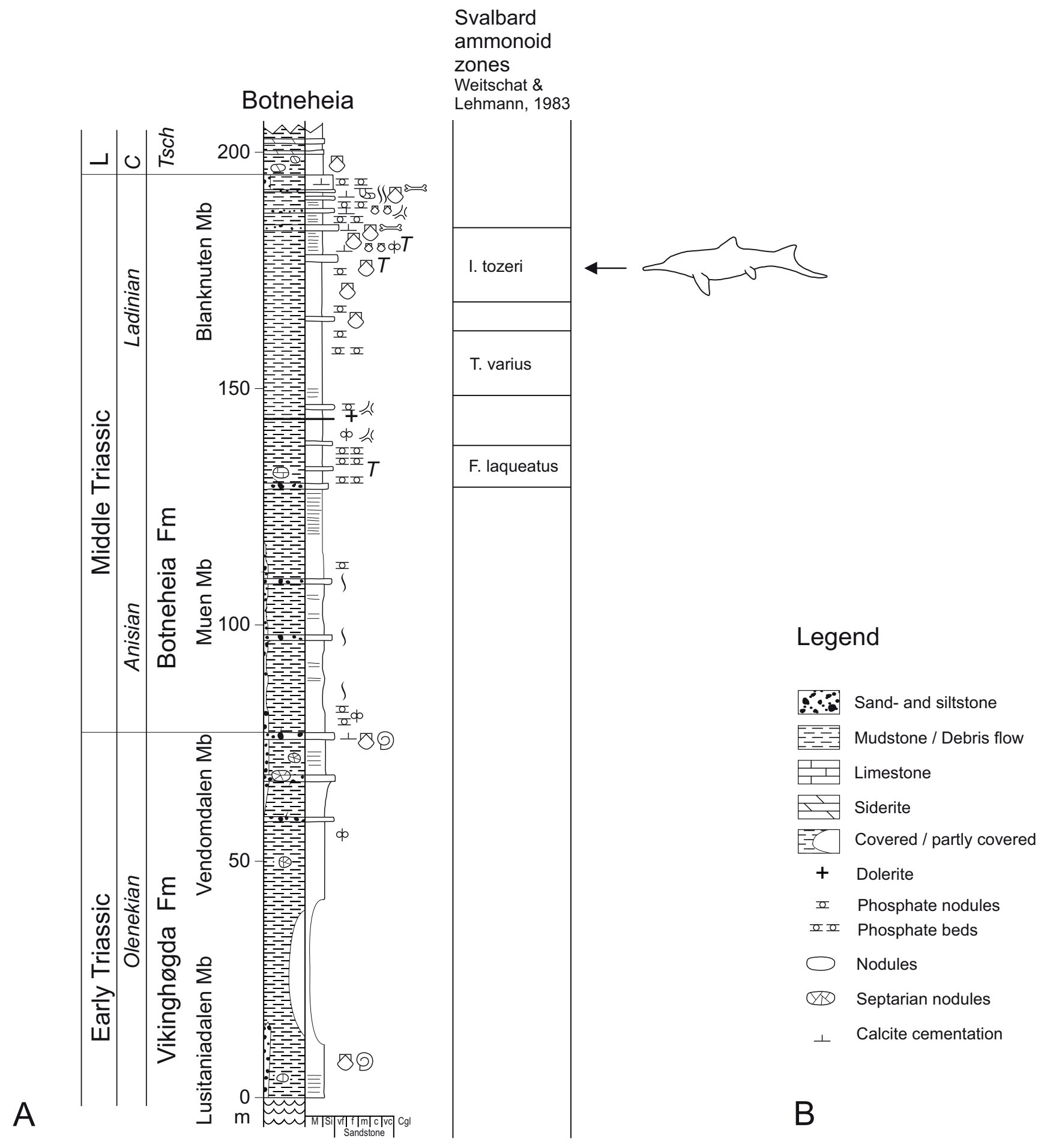

Figure 2. (A) Stratigraphic log of the Botneheia Formation at Botneheia, correlated with the ammonoid zones by Weitschat \& Lehmann (1983). Arrow and drawing indicates the layer in which PMO 210.122 was found. Outline modified from DiBgd, shared on Creative Commons. (B) Legend to the stratigraphic log of the Botneheia Formation. Modified from Vigran et al. (2014, fig. 35a).

are additional slabs. Part of the rostrum, numerous teeth and one opisthotic were completely extracted from the matrix (Table 2).

PMO 219.250 is preserved in the collection of the Palaeontological Museum, Natural History Museum, University of Oslo, Norway. It consists of partially articulated cranial and postcranial material. The specimen is preserved on seven slabs and laterally flattened. A detailed description and figures of this specimen have been published by Hurum et al. (2014).

Preparation - PMO 210.122 was prepared with chemical and mechanical methods. For acid treatments 


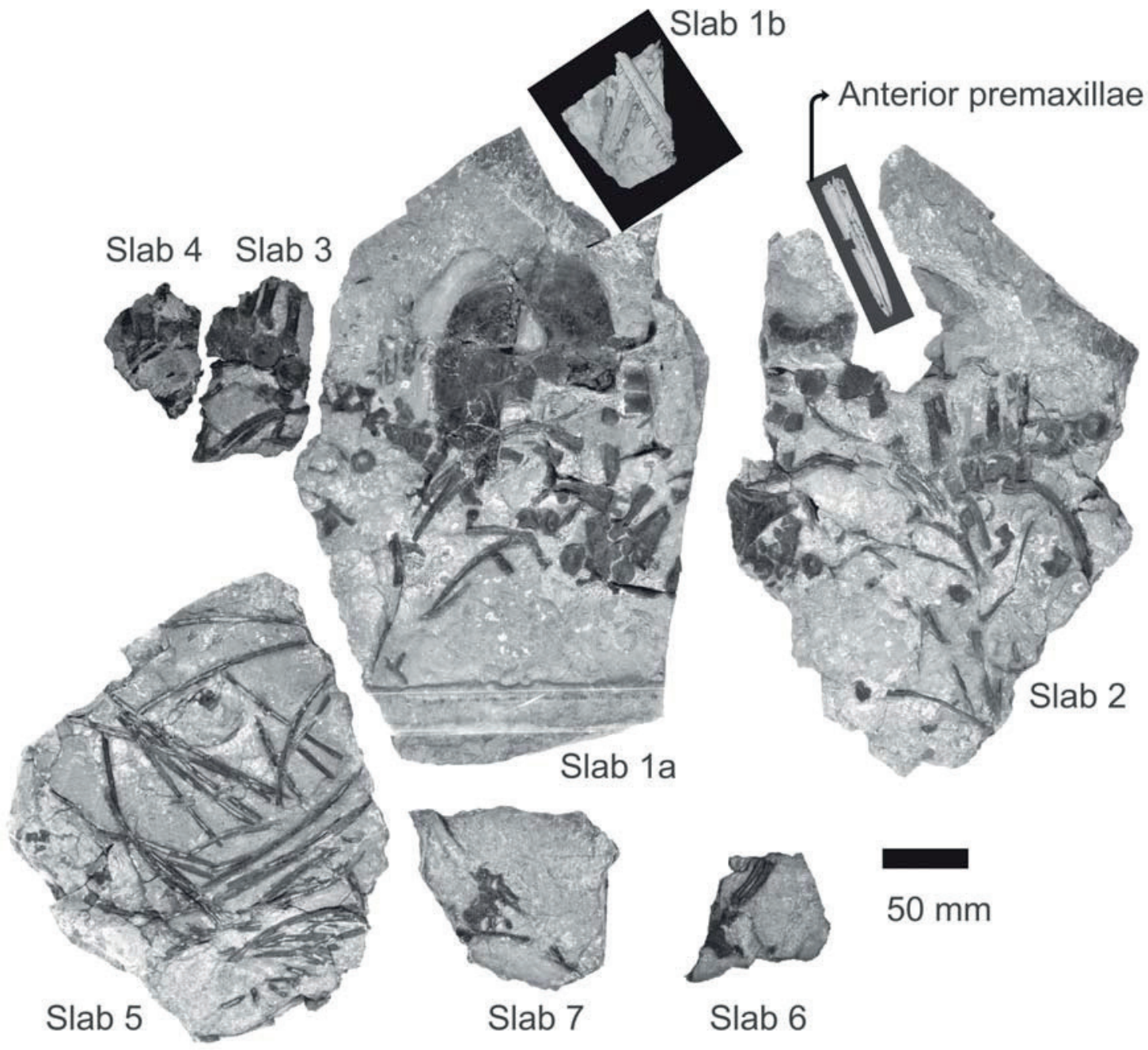

Figure 3. The specimen PMO 210.122 distributed between slabs 1-8 and disarticulated anterior premaxillae. Slabs $1 a, 1 b, 3$ and 4 placed in their relative natural positions, as well as slab 2 relative to the anterior maxillae. Slab 2 is the counterpart of slab 1a. The remaining loose elements, PMO 210.122/10-18, are not included due to size. Slab $1 \mathrm{~b}$ and the anterior premaxillae are shown as $\mu$-CT scan photographs because this method showcased the detailed structures better. For identification of the individual elements, see Figs. 4-13.

Table 1. PMO 210.122, subnumbers of slabs.

\begin{tabular}{cc}
\hline Slab number & PMO number \\
\hline Slab 1a & PMO 210.122/01 \\
Slab 1b & PMO 210.122/02 \\
Slab 2 & PMO 210.122/03 \\
Slab 3 & PMO 210.122/04 \\
Slab 4 & PMO 210.122/05 \\
Slab 5 & PMO 210.122/06 \\
Slab 6 & PMO 210.122/07 \\
Slab 7 & PMO 210.122/08 \\
\hline
\end{tabular}

Table 2. PMO 210.122, subnumbers of loose elements.

\begin{tabular}{cc}
\hline Elements extracted from matrix & PMO number \\
\hline Anterior premaxillae & PMO 210.122/09 \\
Dentary tooth & PMO 210.122/10 \\
Tooth from slab 1b & PMO 210.122/11 \\
Tooth from slab 1b & PMO 210.122/12 \\
Tooth from slab 1b & PMO 210.122/13 \\
Tooth from slab 1b & PMO 210.122/14 \\
Tooth from slab 1b & PMO 210.122/15 \\
Tooth from slab 1b & PMO 210.122/16 \\
Tooth from slab 1b & PMO 210.122/17 \\
Opisthotic & PMO 210.122/18 \\
\hline
\end{tabular}


a $10 \%$ acetic acid solution was used. The elements were impregnated with Mowilithgranulat solved in $96 \%$ ethanol before each treatment with acid.

$\mu$-CT scan and photography $-\mu$-CT scanning was done with a Nikon Metrology XT H 225 ST microfocus CT (see Table E.S. 1 in Electronic Supplement 1 for $\mu$-CT scanning parameters). The density of the bones and the matrix were too similar for any distinct contrast. For this study, only pictures of the surface were used. The remaining pictures were taken with a Nikon D3100 with a Nikon AF-S Micro Nikkor $60 \mathrm{~mm} \mathrm{1:2.8} \mathrm{G} \mathrm{ED} \mathrm{macro}$ objective.

Phylogenetic analyses - Two phylogenetic analyses were carried out using TNT 1.5 beta Willi Henning Society Edition (Goloboff et al., 2008). The original data matrix from one of the most recent phylogenetic studies of the Ichthyopterygia (Ji et al., 2015) was used in the first analysis. We choose to use the Ji et al. (2015) matrix and not the more recent one assembled by Moon (2017) as the resolution for the Triassic taxa is better in Ji et al. (2015). The data matrix was modified for the subsequent analyses using Mesquite v3.04 (Maddison \& Maddison, 2015; see Electronic Supplements 2-4). The same 163 characters from Ji et al. (2015) were included in the data matrices for both analyses, and weighted equally. In each analysis, a New Technology Search was conducted in TNT using rule-3 collapse, level 10, 100 hits, 100 replications, $10 \mathrm{drifts}$ and holding 10 trees per replicate, as described in Ji et al. (2015). A Bremer support analysis was done after each New Technology Search, which included trees no more than 10 steps above the shortest trees. Consistency index and retention index were also calculated using TNT. Tree statistics are displayed in the discussion. The analysis aimed at replicating the results by Ji et al. (2015), using their original data matrix and the same settings. This included two runs, the first in which all 64 taxa were included, and the second in which 11 taxa were excluded, as was done in the first and second analyses by Ji et al. (2015), respectively. In the second analysis, two specimens were included in the data matrix: PMO 210.122 and PMO 219.250. The aim of these phylogenetic analyses was to test the phylogenetic placement of PMO 210.122 in relation to Mixosauridae, with PMO 219.250 as comparative material.

\section{Institutional abbreviations:}

MNHN Museum National d'Histoire Naturelle, Paris, France.

PMO Palaeontological museum, Natural History Museum, University of Oslo, Norway.

PMU Palaeontological Museum, University of Uppsala, Sweden.

\section{Description}

\section{Systematic palaeontology}

\author{
Superorder Ichthyopterygia Owen, 1840 \\ Order Ichthyosauria Blainville, 1835 \\ Family Mixosauridae Baur, 1887
}

Genus Phalarodon Merriam, 1910

Phalarodon fraasi Merriam, 1910

Referred material from Spitsbergen, Botneheia Formation, Middle Triassic: PMU 24555, PMU 24561, PMU 24579, PMU R 102, PMU R 516, PMU R 518; MNHN 328; PMO 210.122.

PMO 210.122

Skull - The cranial skeleton includes parts of the upper and lower jaw, an incomplete sclerotic ring and the right opisthotic. Selected measurements of the skull are displayed in Table 3.

Upper Jaw - The premaxillae are preserved in two parts (Figs. 4 \& 5). The preserved snout is not complete in the entire anterior-posterior length, but terminates posteriorly. The posterior portion of the premaxillae is exposed in ventral and partly lateral view, revealing teeth and sockets, and in posterior view, exposing a vertical cross section of the snout. Some sections of the dorsal surface are damaged. The posterior edge of the rostrum might be from the maxillae, but the possible sutures between the premaxillae and maxillae are covered by matrix. A $\mu$-CT scan of the upper jaw did not reveal the sutures. The premaxillae are elongated giving the impression of a long, slender snout as in other mixosaurids (Nicholls et al., 1999; Jiang et al., 2007), and are convex dorsolaterally. Anteroposteriorly oriented coarse surface striations, which might also encompass foramina, are visible on the undamaged bone surface, in dorsal and lateral views. The medial premaxillary symphysis is deep and defined, and the suture between the left and right premaxillae is clear. There is a gap between the premaxillae, which is narrow anteriorly, but widens posteriorly. Anteriorly the teeth are closely spaced, while the teeth are more widely spaced

Table 3. Selected skull element measurements of PMO 210.122.

\begin{tabular}{lc}
\hline Selected skull element measurements & $\mathrm{mm}$ \\
\hline Length of preserved snout & 175.0 \\
$\begin{array}{l}\text { Width of hollow space within upper jaw at most pos- } \\
\text { terior point (breakage zone) }\end{array}$ & 15.0 \\
Palatine length (from anterior edge to breakage point) & 171.0 \\
Length of dentary & 74.4 \\
Labial-lingual width of tooth A & 2.8 \\
\hline
\end{tabular}




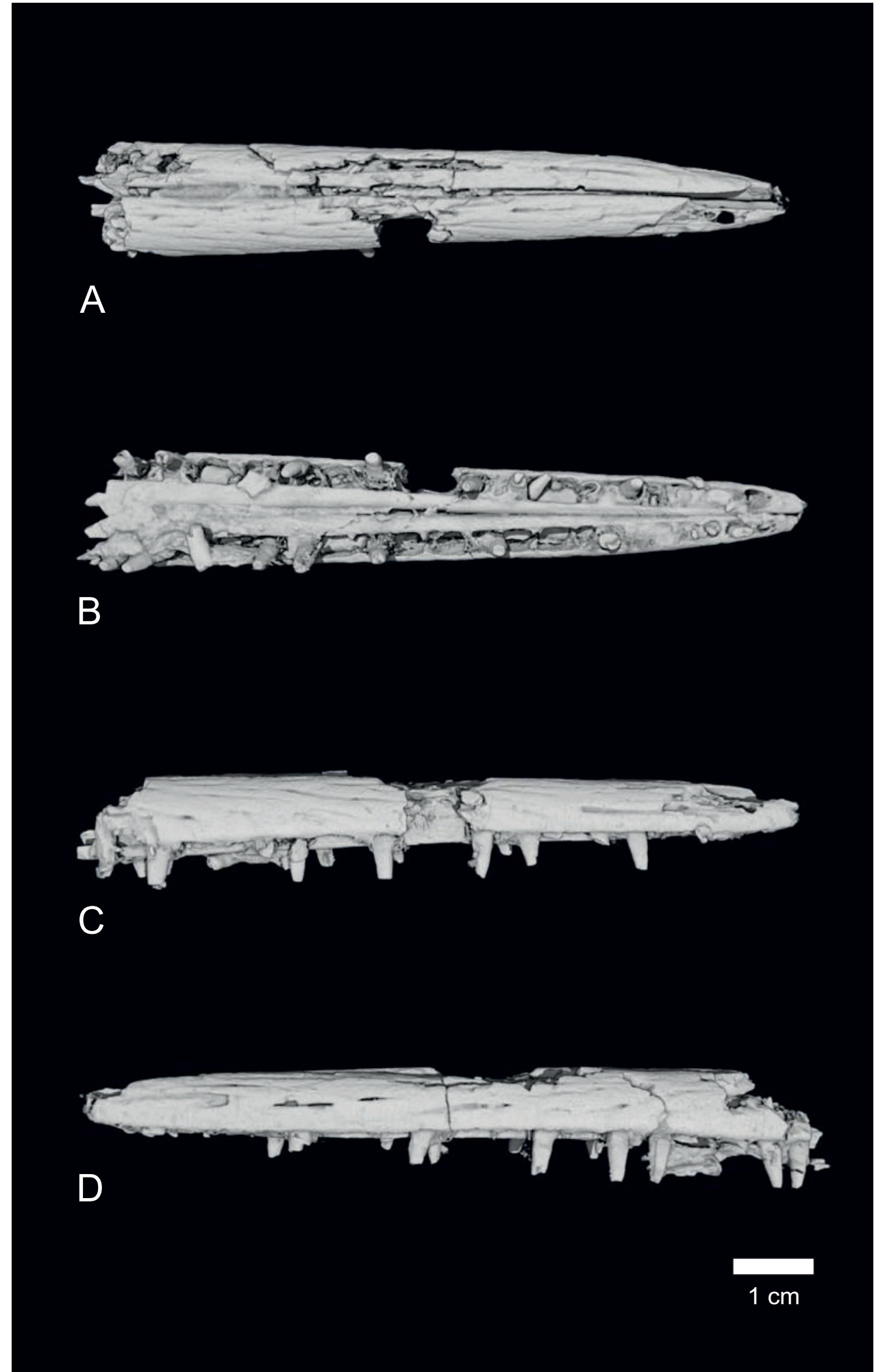

Figure 4. $\mu$-CT scan photographs of the rostrum of PMO 210.122/09. (A) Dorsal view. (B) Ventral view. (C) Right lateral view. (D) Left lateral view.

posteriorly, as is also observed in the mixosaurid PMO 219.250 .

The preservation of the sockets is variable, from easily identifiable to completely covered by matrix. The sockets are separated by alveolar walls, and are deep, such that the length of the tooth crowns nearly equals the length of the roots. These partitions are thin and damaged anteriorly, but they become more robust and better preserved posteriorly. Small sockets are situated adjacent to larger sockets, which may have contained smaller teeth or showing an uneven pattern of tooth replacement, unlike 


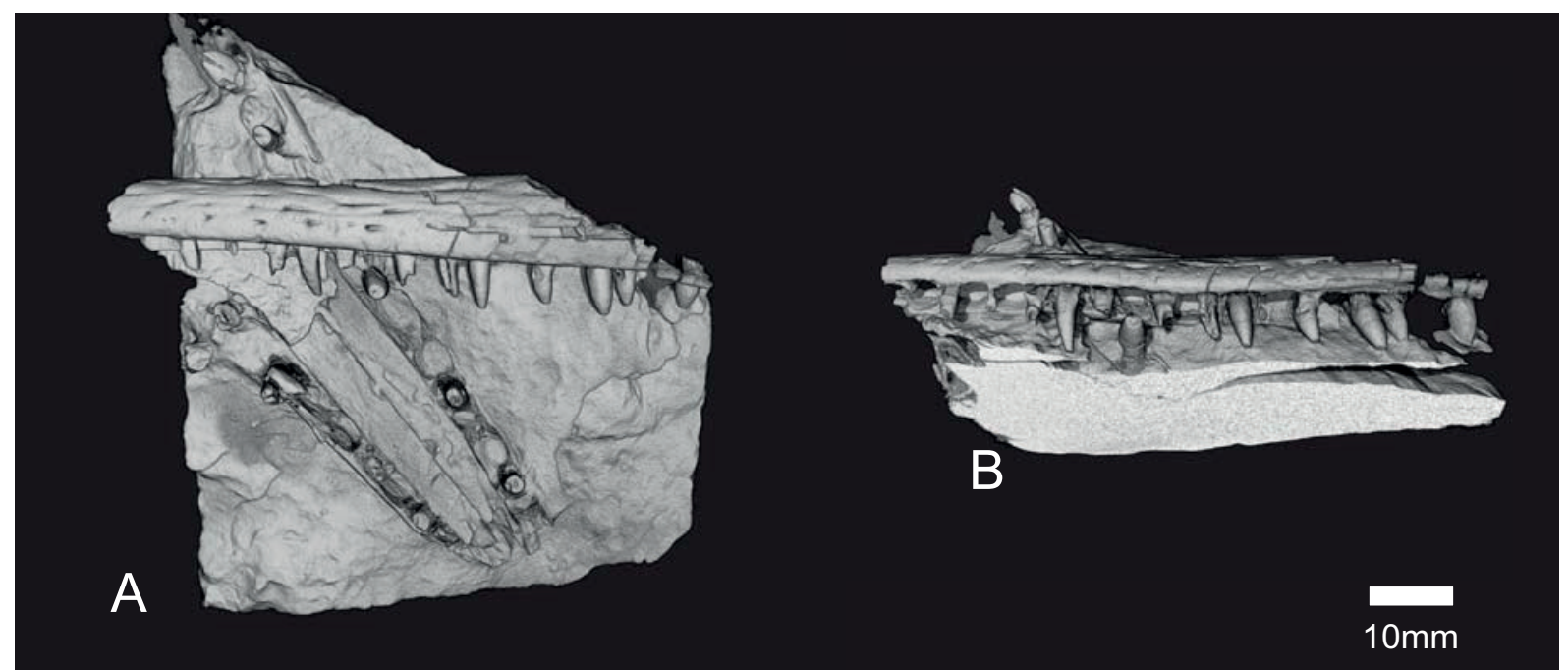

Figure 5. $\mu$-CT scan photographs of jaw elements of PMO 210.122/02 on slab 1b. (A) Posterior portion of rostrum in ventral view, and midsection of right dentary in lateral view. (B) Dentary in dorsolateral view.

what is known for Cretaceous ichthyosaurs (Maxwell et al., 2011). This is also seen in the lower jaw (see dentary dentition below).

Vomer - A small fragment of the right vomer is exposed in ventral view in the posterior edge of the upper jaw. It is covered by matrix anteriorly, such that the shape of the anterior tip, as well as the anterior sutures, cannot be discerned. The suture between the premaxilla and the vomer is a tight articulation. The left vomer is covered entirely by matrix.

Lower Jaw - The middle section of the dentary is preserved in right lateral view (Fig. 5). In the ventral section of the dentary a suture to the underlying surangular might be present. Other bone elements are visible at the breakage point of the dentary at the posterior edge, but these are too covered by matrix to reveal any features. The bone is slender and equally laterally convex as the premaxillae. As with the premaxillae, coarse anteroposteriorly oriented surface striations with foramina cover the lateral surface. The teeth are set in slightly anteroposteriorly elongated sockets, which are well preserved, and closely spaced. A small horizontal shelf of the dentary on the labial side of the teeth in dorsal view offsets the teeth slightly towards the lingual margin. The labial shelf becomes broader and more pronounced posteriorly.

Dentition - 31 partial teeth are preserved set in the upper jaw, situated in sockets. The right tooth series contains 39 identifiable sockets with 17 preserved teeth, and the left tooth series contains 33 identifiable sockets in which 14 teeth are preserved. Of the preserved, exposed teeth in the right tooth series, 13 are nearly complete. Of the remaining three only the roots are preserved. In the left tooth series seven teeth are nearly complete, while the remaining teeth are damaged, usually with only the root preserved. More sockets might be hidden under the cover of the dentary and matrix. One tooth is completely covered by the dentary and matrix, and its presence was exclusively discerned through the $\mu$-CT scan. The teeth are slightly curved. As the exact location of the transition between the premaxilla and the maxilla is not known, the allocations of the teeth posteriorly to either of the bones are not possible. The most posterior teeth probably belong to the anterior part of the maxillae, indicated by their robust appearance and the width of the snout. Both tooth rows are placed within alveoli separated with transverse partitions. Anteriorly, in the more damaged sections of the premaxilla, the alveolar bone spanning the dental groove are poorly preserved, creating a dental groove with only slight partitions. The alveolar bone spanning the dental groove in the posterior part of the premaxilla is thicker, and more frequently preserved than those found anteriorly. The alveolar bone reaches as high as the labial and lingual wall, and is thus different from the rudimentary bony septa observed in previous studies (Maisch \& Matzke, 1997; Motani, 1997), more like what is seen in other diapsids like dinosaurs and crocodilians (LeBlanc et al., 2017). The anterior teeth are all slender and conical. They have a smooth surface both on the root and the crown, and the socket walls are smooth. The apex is preserved on three teeth, where it is blunt. The teeth are laterally compressed. The posterior teeth are conical, and more robust compared with the anteriorly situated teeth. The posterior teeth are laterally compressed, with smooth crown surfaces and root striations. The socket walls are covered by vertical furrows, which match the striations of the teeth. The apices are blunt, but only preserved on two teeth. The most posteriorly preserved tooth is the most robust. The root of this tooth is exposed posteriorly, revealing clear surface striations, indicating an ankylosed attachment of the tooth to the socket. The root and the crown appear to be of equal height, and the socket is deep. Thus, an ankylosed thecodont attachment of the posterior teeth as described for Mixosauridae by Motani (1997) seems likely. 


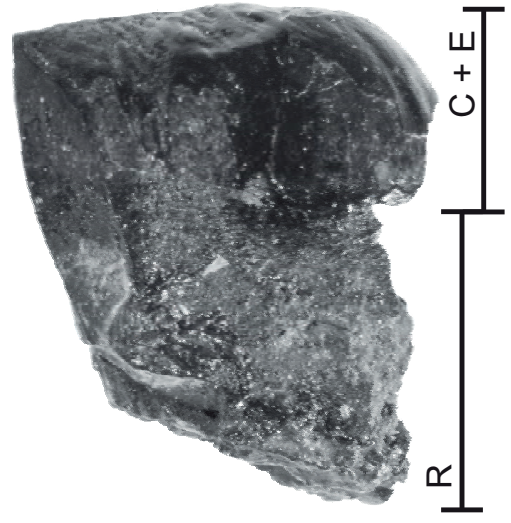

A

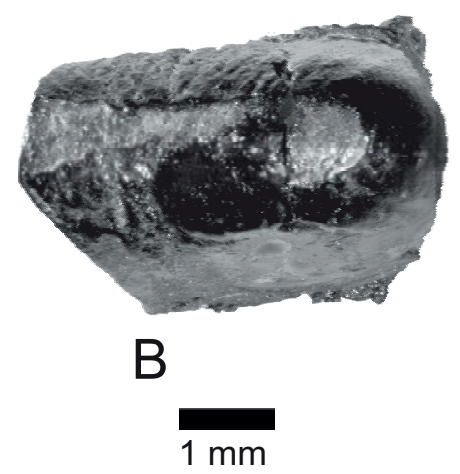

$1 \mathrm{~mm}$

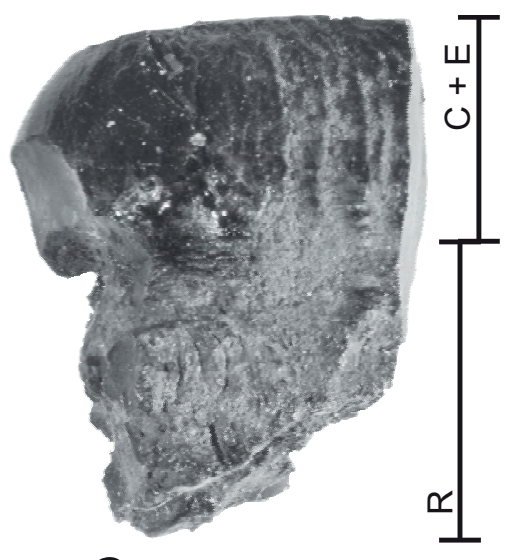

C

Figure 6. Photographs of the most posteriorly preserved dentary tooth of PMO 210.122/10. (A) Labial view. (B) Dorsal view of mesiodistal ridge. (C) Lingual view. Abbreviations: $R$ - root, $C$ - crown, $E$ - enamel.

The preserved midsection of the right dentary contains 20 sockets, in which 12 teeth are preserved. The teeth are evenly spaced. Five of the teeth are heavily damaged at the tooth crown, while the remaining seven teeth are complete or nearly so. The anterior teeth are conical and slender, but they become gradually more robust posteriorly. In addition, the relative height of the tooth crowns becomes shorter posteriorly. The teeth seem to be paired with a shorter tooth anterior to a longer tooth, but this needs more specimens to be confirmed. This might be similar to what has been observed by Brinkmann (2004, fig. 29). The transition between conical and flat teeth is abrupt, as the planar tooth is situated adjacent to a conical tooth. The apices of the conical teeth, where preserved, are blunt. While the crown is always smooth, with ridges in the enamel, some of the anterior teeth are striated or contain grooves on the surface of the root. The presence of grooves at the base of the teeth is especially apparent from the three-dimensional data provided by the $\mu$-CT scan. All the conical teeth, which are adequately preserved in their whole length, show a constriction of the teeth, separating the root from the crown. This feature was also observed in the maxillary teeth of a specimen of Phalarodon cf. fraasi (fig. 3 in Jiang et al., 2007). The most posterior tooth preserved (Fig. 6) became disarticulated during preparation, revealing more information as the lingual side was exposed. It has a distinctly different morphology from the anteriorly positioned teeth, being almost square in labial view (Fig. 6A). The morphology of this tooth is considered an original condition, as no indications of compaction are present, and the tooth was preserved immediately adjacent to a perfectly preserved conical tooth. Supporting this view is the fact that none of the other teeth on the dentary are compressed, and detailed structures such as the surface striations are preserved. The tooth is elongated in the mesiodistal direction, forming a crown ridge (Fig. 6B). The crown ridge is rounded in the labiolingual direction. A constriction of the tooth is visible on the lingual side of the tooth, in the transition between the crown and the root. Weak longitudinal enamel ridges are visible in the enamel on the lingual side of the tooth (Fig. 6C), while the surface of the labial side is smooth. The enamel ridges are stronger at the centrum of the mesiodistal extent of the enamel, and abate towards the mesial edge of the tooth. The morphology of the tooth with regard to the mesiodistal ridge is similar to the teeth in the holotype of $P$. fraasi (fig. 2 in Motani, 2005), and is also observed in P. fraasi from Svalbard (PMU R102 (Schmitz et al., 2004); this feature is typical for the species (Nicholls et al., 1999; Motani, 2005). A fully preserved posteriormost mandibular dentition of Phalarodon sp. from Svalbard with a very similar shape is known (fig. 7 in Maxwell \& Kear, 2013). Mesiodistally elongated posterior teeth were also observed in the upper and lower jaw of Phalarodon sp. (fig. 1 in Jiang et al., 2003). Even though slight heterodonty occurs in specimens of Mixosaurus, their posterior tooth crowns are rounded rather than flat (PMO 219.250; M. cornalianus, PMU R432 (plate 11:1 in Wiman, 1912) and M. panxianensis, figs. 3 \& 4 in Jiang et al., 2006), whereas rounded - approximating flat crushing teeth have been reported in M. kuhnschnyderi (fig. 4 in Brinkmann, 1998a, see also Brinkmann 2004).

Seven loose teeth emerged from the matrix of slab $1 \mathrm{~b}$ (Fig. 7). They were in different states of preservation, from damaged to nearly complete, and some were gracile with conical apices while others were quite robust with blunt apices. Discernible from these teeth is the presence of enamel ornamented with ridges, and a separation of the crown from the root by a distinct constriction. Several of the teeth have gentle grooves in the upper surface of the root transitioning into an infolding at the base of the tooth, resulting in a plicidentine condition, also observed in P. atavus (plate 1: 17-18 in Fraas, 1891), P. callawayi (plate 4 in Schmitz et al., 2004), P. major nomina dubia (fig. 5 in Maisch \& Matzke, 2001a) and Phalarodon sp. (fig. 1 in Jiang et al., 2003). 


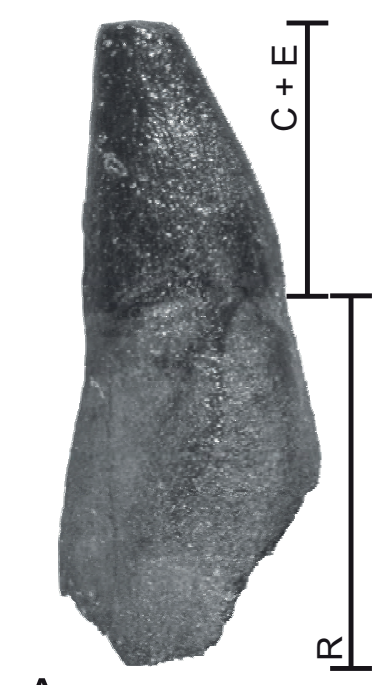

A

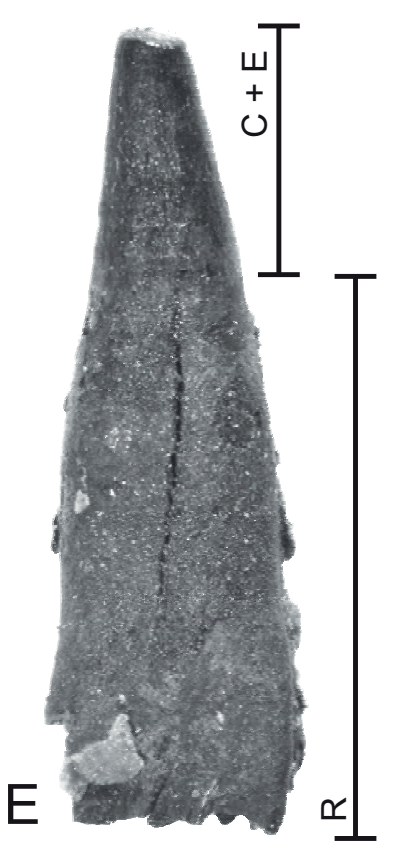

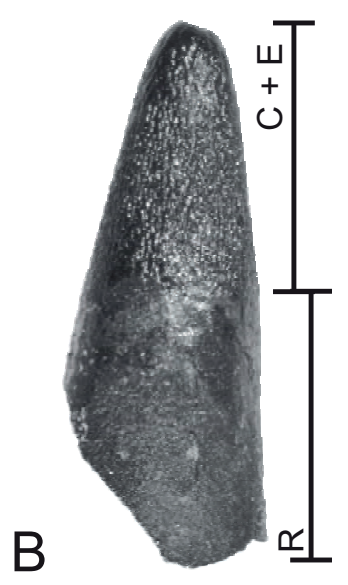

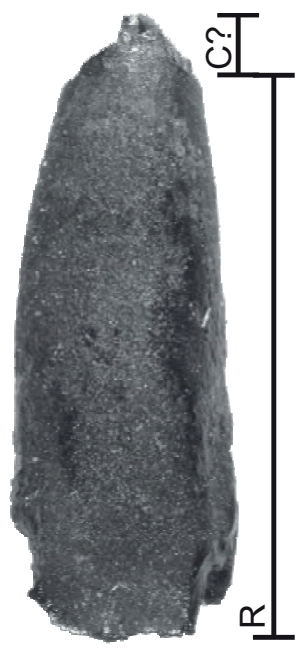

C
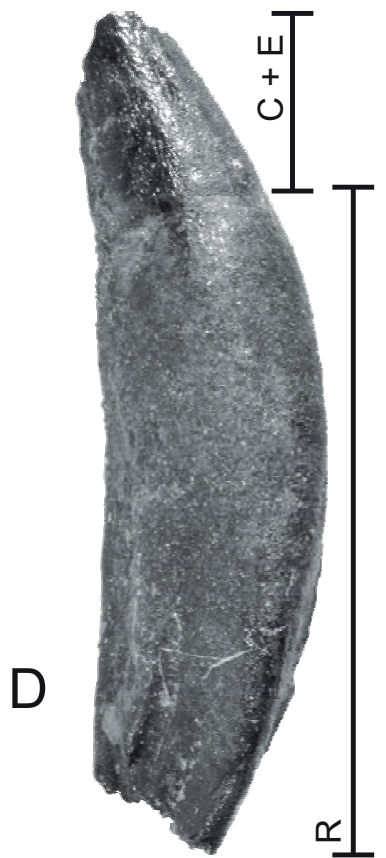

$1 \mathrm{~mm}$
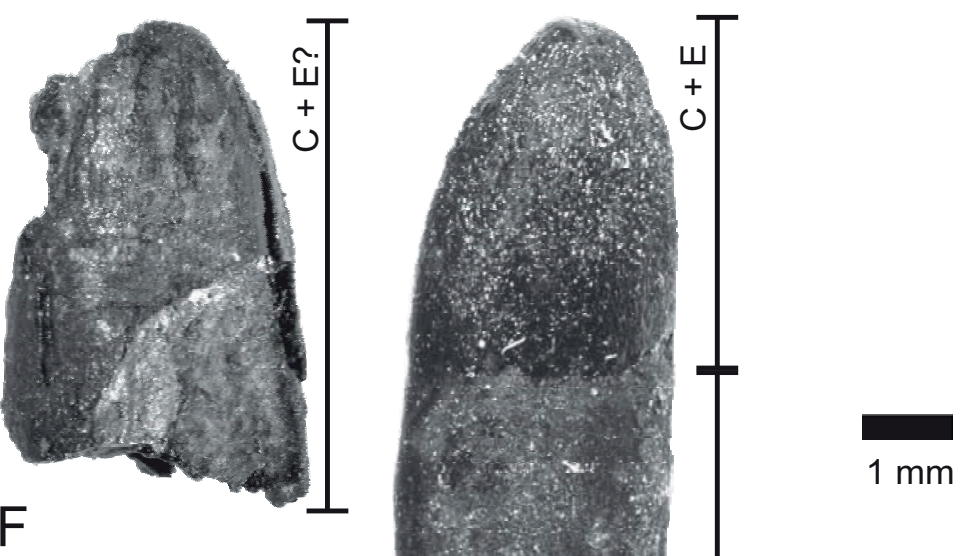

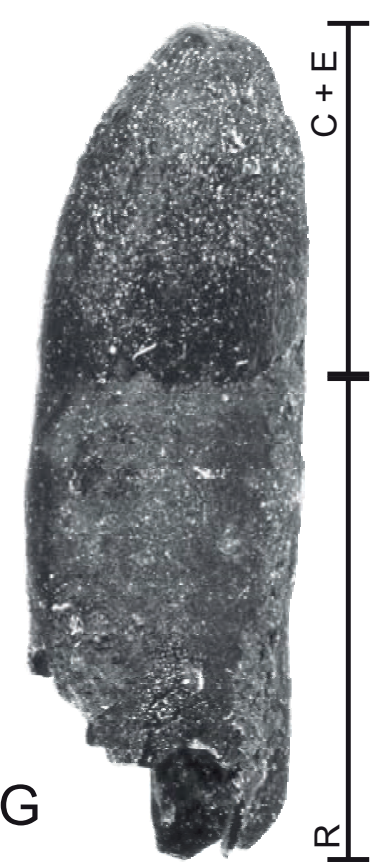

Figure 7. Photographs of loose teeth of PMO 210.122 from slab 1b. (A) Slender, conical tooth with a constriction at the root-crown transition, and a blunt apex (PMO 210.122/11). (B) Slender, conical tooth with blunt apex, in which the enamel ridging is easily visible (PMO 210.122/12). (C) Conical tooth in which almost all the crown is missing (PMO 210.122/13). (D) Slender, conical tooth in which the whole root is preserved, showing the infolding and plicidentine condition (PMO 210.122/14). (E) Slender, conical tooth with infolding at the root (PMO 210.122/15). (F) Rounded tooth crown of a robust tooth (PMO 210.122/16). (G) Robust, conical tooth with a rounded tooth crown (PMO 210.122/17). Abbreviations: $R$ - root, $C$ - crown, E - enamel, ? - uncertainty.

Cranial skeleton - A partial sclerotic ring is preserved as thin bones (Fig. 8), and thin bone fragments (Fig. 9). Six articulated plates are preserved, and are all damaged to some extent. They form a semicircular structure in which the plates are linked to each other with curved sutures. The outer rim of the plates is damaged, while the internal margin is better preserved. The inner parts of the plates are gently convex, although this could be either an original state or due to deformation. The morphology of the sclerotic ring seems similar to the sclerotic rings observed in Phalarodon callawayi (plate 4, text-fig. 5 in Schmitz et al., 2004), although the cross-section of the lateral surface in PMO 210.122 cannot be discerned. 
Opisthotic - The element tentatively identified as the right opisthotic is based on the relative robust medial margin and thin paroccipital process as seen in Maisch et al. (2006). The bone was extracted from the matrix, and is well preserved (Fig. 10). The lower two-thirds of the posterior surface of the distal paroccipital process is preserved as a thin film of bone on slab 2 (Fig. 8). The ventral margin of the element is broken off. Compared to the rest of the element the medial margin is robust, and has a triangular shape with a dorsoventral groove, which might be an impression of a canal. The medial margin presumably formed an articular surface to the basioccipital ventrally and the exoccipital dorsally, although the individual facets are indistinguishable. The paroccipital process is long and plate-like, which is an unusual feature among ichthyosaurs, previously observed in Mixosaurus cf. cornalianus (fig. 1 in Maisch et al., 2006) and Phantomosasaurus neubigi (fig. 2 in Sander, 1997; fig. 1 in Maisch \& Matzke, 2006). The paroccipital process is slightly thicker dorsally, with a thinning of the process in both ventral and distal direction. A posteriorly protruding ridge is formed by the thickening of the process just dorsally to the mediolateral centrum of the element. The posterior surface is smooth, and anteriorly oriented in the lower two-thirds of the bone. There is a curved longitudinal indentation medioventrally on the posterior surface, which might be an impression of a canal. A small ridge separates the posterior and medial margins. The anterior margin is concave, curving into a groove in the mediolateral direction. The concavity is stronger medially, and straightens out slightly laterally. The anterior surface is rugose, but with no clear demarcated facets. The distal margin of the paroccipital process is partly broken ventrally, and gently convex distally.

Axial skeleton - Axial element measurements are listed in Table 4, including the height and length measurements for all preserved vertebrae.

Atlas-axis complex - The unfused atlas-axis complex is best preserved on slab 1a, in right lateral view (Fig. 9 ), while the remains of the broken surfaces of these elements are preserved on slab 2 (Fig. 8).

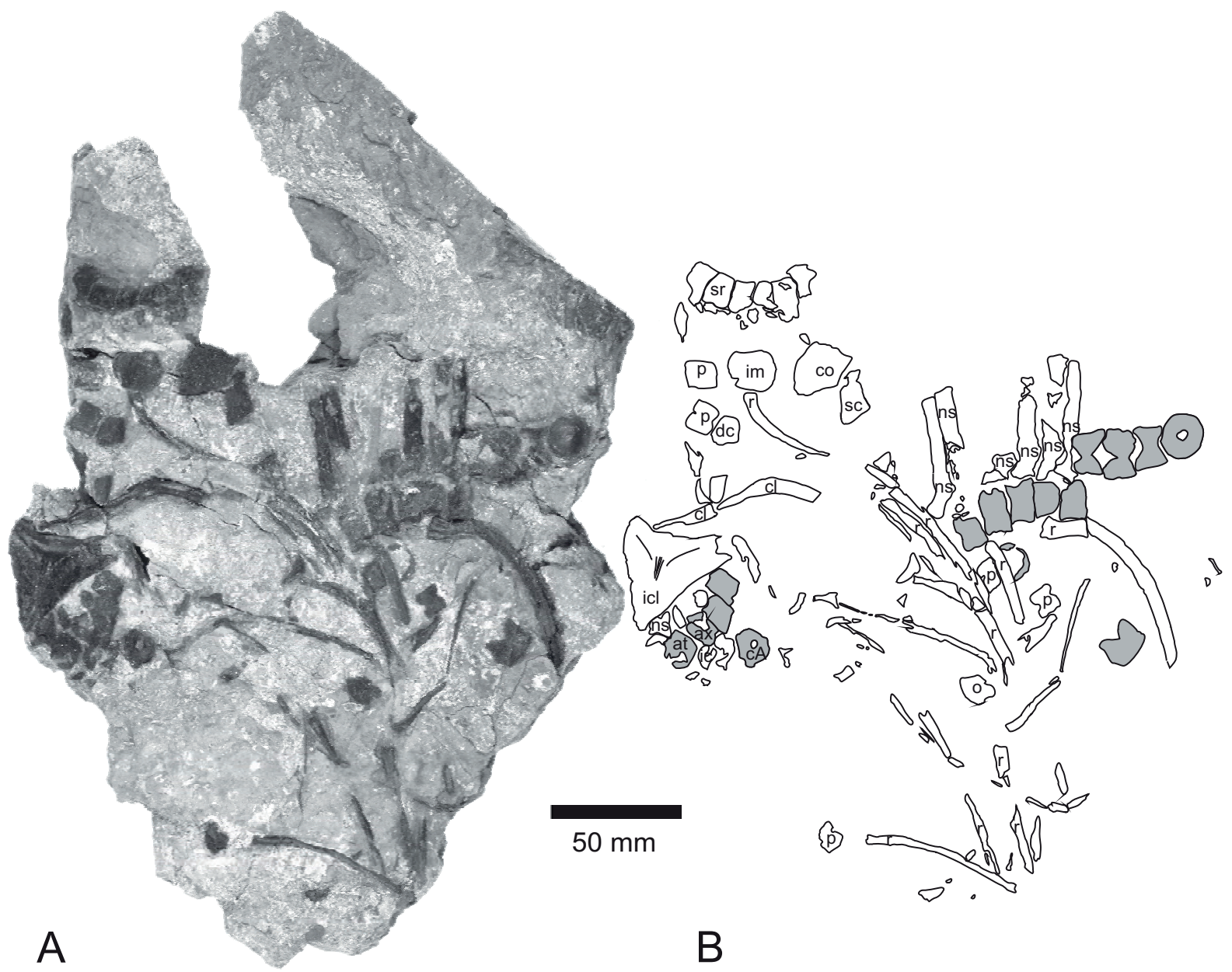

Figure 8. (A) Slab 2, with sclerotic ring and axial and appendicular skeleton elements of PMO 210.122/03. (B) Interpretive drawing, with

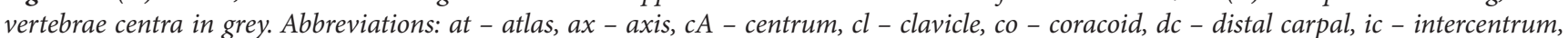
$i c l$ - interclavicle, im - intermedium, $n s$ - neural spine, $o$ - opisthotic, $p$ - phalange, $r$ - rib, sc - scapula. 
Table 4. Selected axial element measurements of PMO 210.122

\begin{tabular}{lc}
\hline Selected axial element measurements & $\mathrm{mm}$ \\
\hline Axis height (dorsal to ventral margin) & 16.1 \\
Axis length (anterior to posterior margin) & 9.1 \\
Height of neural canal opening on neural spine & 5.9 \\
Width of neural canal opening on cervical neural arch & 8.2 \\
Width of anterior dorsal centra E & 21.3 \\
Height of anterior dorsal centra E & 17.2 \\
Width of anterior dorsal centra F & 21.9 \\
Height of anterior dorsal centra F & 17.5 \\
\hline
\end{tabular}

Centra - The atlas is shifted such that it is exposed at its anterolateral margin. The surface of the right lateral margin is broken. The anterior surface of the atlas is slightly concave, forming the atlantal cup. The neural arch articular facets are preserved anteriorly on the dorsal surface, and are ventrally concave. The axis is mostly complete although some of the surface is broken off, and exposed in right lateral view. The anterior margin is dorsally straight, and in articulation with the atlas. The ventral part of the anterior margin is tilted posteriorly, which together with the atlas is making an opening in which intercentrum 2 articulates. The posterior margin of the axis is straight. The neural arch articular facets are preserved anteriorly on the dorsal surface, and are ventrally concave. A single rib articular facet is situated anterodorsally on the lateral margin of the axis.

Intercentra - A small elongated element situated anteroventrally to the atlas is interpreted to be the disarticulated intercentrum 1 . The orientation and morphology of the element are uncertain due to damage, but an expansion at the edge of the elongated bone is interpreted to be the anterior section when compared with intercentrum 1 of the holotype of Phalarodon callawayi (plate 5 in Schmitz et al., 2004). Intercentrum 2 is a small, triangular element with blunt edges. It is wedged in between the atlas and the axis. The surface is slightly broken, mostly on the anterior margin. The anterior margin is slightly convex, while the ventral margin is slightly concave. The posterior margin is

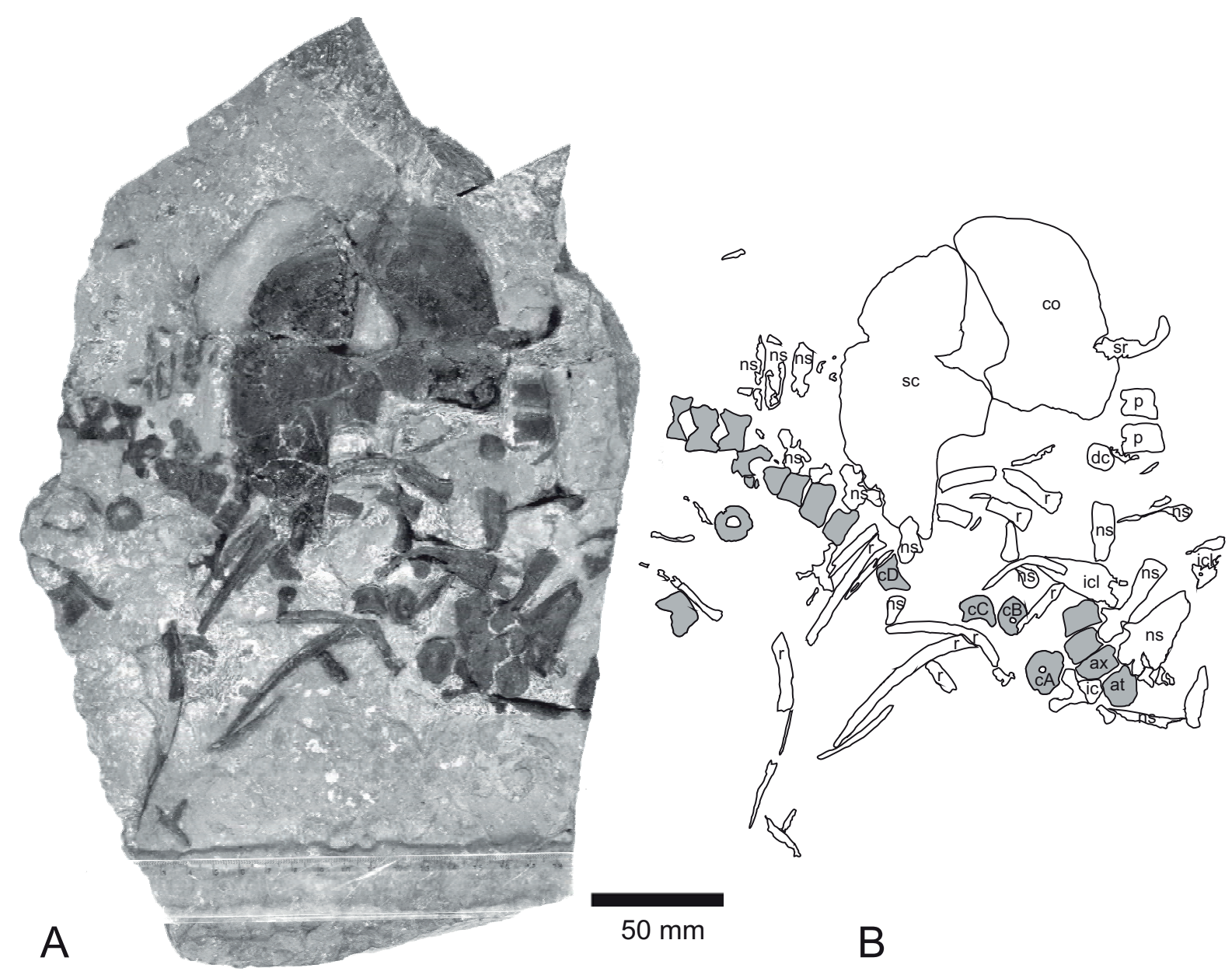

Figure 9. (A) Slab 1a, with axial and appendicular skeleton elements of PMO 210.122/01. (B) Interpretive drawing, with vertebrae centra in grey. Abbreviations: at - atlas, ax - axis, cA-D - centrum, co - coracoid, dc - distal carpal, ic - intercentrum, icl - interclavicle, ns - neural spine, $p$ - phalange, $r$ - rib, sc - scapula. 
straight. Intercentrum 2 is very similar in both shape and position to the corresponding element of the holotype of P. callawayi (plate 5 in Schmitz et al., 2004). Neural arch 1 is incomplete as fragments on slab $1 \mathrm{a}$ and slab $1 \mathrm{~b}$. It can be recognised by the articulation with the atlas, while it is hard to discern the boundary with neural arch 2 due to preservation. Neural arch 1 and 2 are easily discernible elements in the holotype of Phalarodon callawayi, which does not fuse together, but have slightly overlapping positions (plate 5 in Schmitz et al., 2004). Neural arch 2 is articulated to the axis. It extends dorsally to form the axis neural spine, which is high and elongated anteriorly, and has a triangular shape. It is mediolaterally robust in comparison to the posteriorly positioned neural spines, as is also observed in the holotype of P. callawayi (plate 5 in Schmitz et al., 2004). Dorsally, the element narrows anteroposteriorly to a blunt end. Posteriorly, the axis neural arch is in loose articulation with neural arch 3, with the tip of the long postzygapophyses lying on the anterior tip of the prezygapophyses of neural arch 3 . Thus, only the tips of the facets are in contact, which may indicate a closer articulation than observed.

Cervical centra - Centra 3 and 4 are exposed in lateral view in articulation with the atlas/axis complex (Fig. 9). They are distinctly dorsoventrally higher than anteroposteriorly long. The neural arch facets are preserved in lateral view on both centra. The neural arch facet on centrum 4 is also visible in dorsal view, which reveals a deep depression with a surrounding ridge. Neural arch 3 is articulated with centrum 3, and extends dorsally to form a long and slender, dorsally flattened neural spine. Four centra (centra A-D in Fig. 9) are tentatively identified as cervical centra due to their similarities in shape and size and close proximity to the atlas-axis complex. They are completely disarticulated, preserved between the atlas-axis complex and a row of articulated vertebrae (Fig. 9). Centrum A is positioned closest ventrally to the atlas-axis complex, and is exposed in anterior view (Fig. 9). Both diapophyses and one small parapophysis are intact, indicating a double articulation with the ribs. This is in contrast to the observations of cervical centra in Phalarodon fraasi (text-fig. 2, text-fig. 4 in Nicholls et al., 1999; plate 1 in Schmitz et al., 2004), in which a single rib articular facet is observed. In contrast, Brinkmann (1998b) reported on the presence of double rib facets in the cervical region in Mixosaurus cornalianus, $M$. kuhnschnyderi and M. cf. fraasi (now P. cf. fraasi). The diapophyses are rounded protrusions. The parapophysis protrudes as a much smaller eminence. The floor of the neural canal is wide, occupying the entirety of the dorsal surface of the centrum in anterior view. The centrum is slightly disarticulated from the neural arch. The neural arch is also preserved in anterior view, but the surface is somewhat broken. The arch encloses an opening for the neural canal. Centrum B is in close proximity to the atlasaxis complex and is slightly covered by a rib. The two remaining centra, $\mathrm{C}$ and $\mathrm{D}$, are preserved in lateral view. Few features can be discerned from them, as they are mostly covered with matrix. The depression of the neural arch facet, which is observed on the atlas, axis and centra 3 and 4 , is present on centrum C.

Anterior dorsal centra -17 centra are preserved in articulation or close to their original position, extending from slabs 1a and 2, through slab 3 to slab 4 (Figs. 3, 8, $9,11 \& 12)$. They encompass a part of the vertebrae series tentatively identified as the anterior dorsal section, based on the dorsal position of the diapophyses (Schmitz et al., 2004). All centra are higher than long, and the height/length ratio stays approximately constant at 1.8 throughout the anterior dorsal region. The height/ length ratio was measured to be about 2 in the anterior dorsals of Phalarodon fraasi in Schmitz et al. (2004). They also reported a large variation of this ratio within the mixosaurids. The centra are deeply biconcave, and in centrum $\mathrm{F}$ (Fig. 11A, B), in which all the matrix was removed, a persistent notochordal foramen is present, a feature also observed in $P$. atavus (Fraas, 1891). The diapophyses are easily observed dorsolaterally positioned in several centra as a protruding eminence, and are not confluent with the neural arch facets. There is no indication of the presence of a parapophysis. The corresponding neural arches are extended dorsally to form narrow, straight and long neural spines, with squared-off termination. The neural arches are on average three times as high as the height of the corresponding centra. The features of the neural spines are characteristic for the Mixosauridae, and have been observed in many specimens, including $P$. fraasi (text-fig. 10 in Nicholls et al., 1999; plate 1 in Schmitz et al., 2004; PMU 24579, pers. obs. I.H. Økland) and P. callawayi (PMU 24580, pers. obs. I.H. Økland). The neural arches retaining their articulation with their centrum are dorsally oriented.

Ribs and gastralia - The ribs are disarticulated, none are complete, and most of them lack the proximal and distal ends. Some of the rib fragments are preserved with a single rib head intact, which is broad and flat, widening out in a small fan shape, with a groove following the lateral margin along the anterior or posterior surface (Figs. $8 \& 10$ ). The articular facet is wide, with a straight or slightly convex margin. Some rib fragments are also preserved on slabs 3, 4, 5, 6 and 7 (Figs. 11, 12 \& 13). Several gastralia are preserved on slab 5 , with only the midsection preserved (Fig. 13). The gastralia are identified according to Hurum et al. (2014) as small elongated elements with rounded cross-sections, about half the thickness of the ribs.

\section{Appendicular skeleton}

Measurements are listed in Table 5.

Pectoral girdle - The scapula (Fig. 9) is preserved in articulation with the coracoid, probably in life position (fig. 10 in von Huene, 1916). Whether the scapula and 


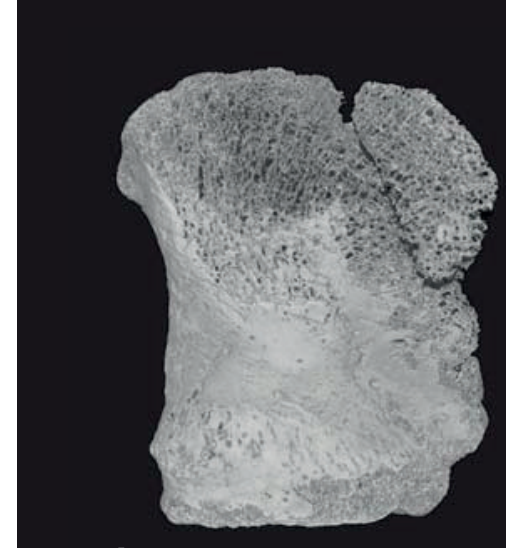

A

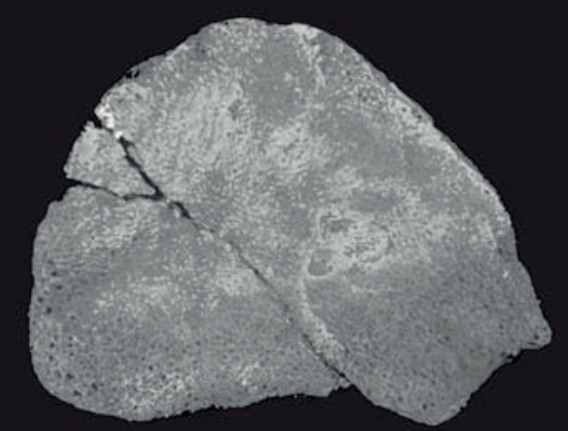

C

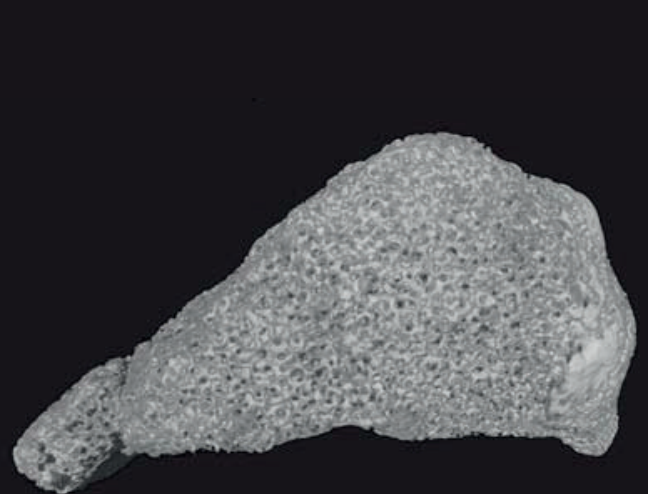

E

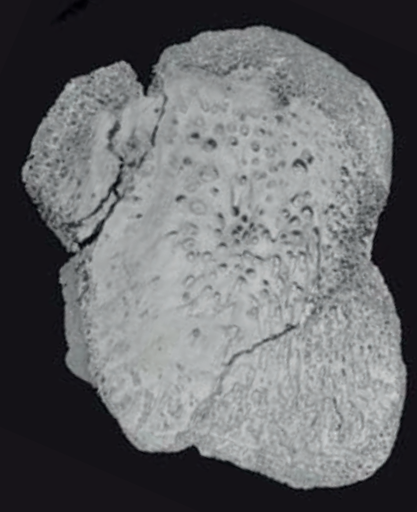

B 


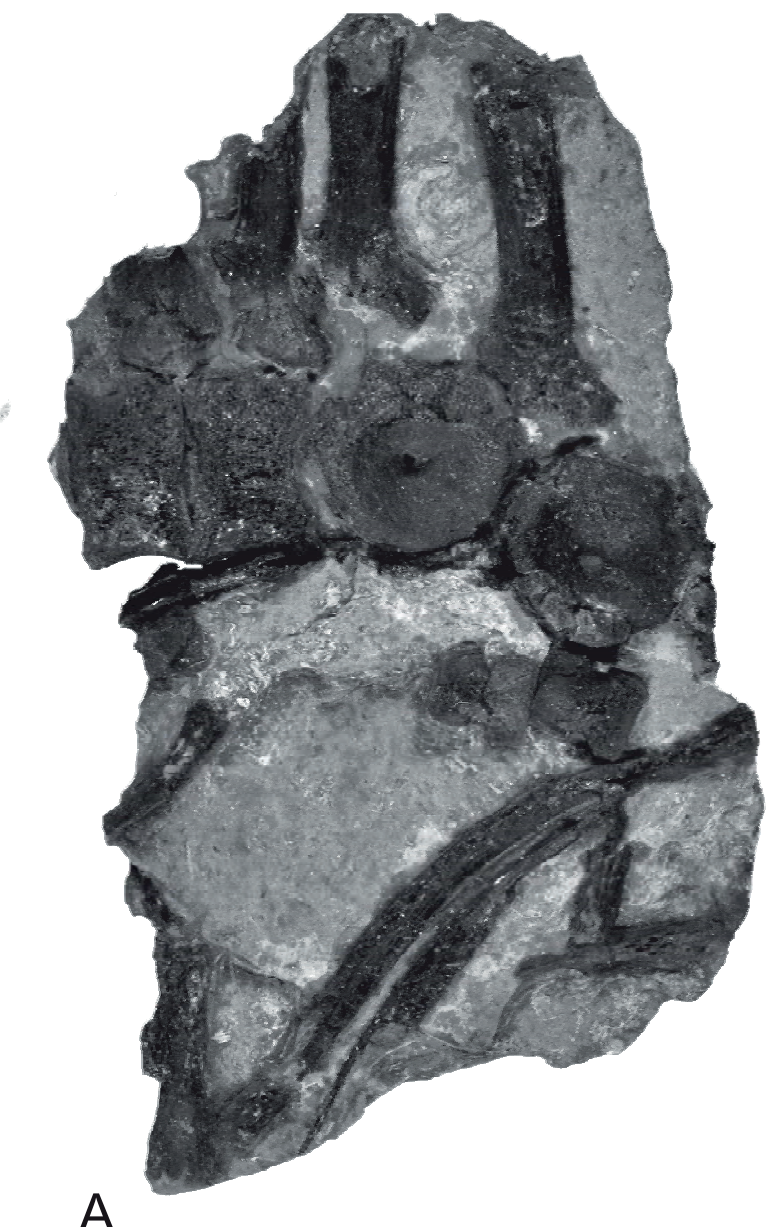

A

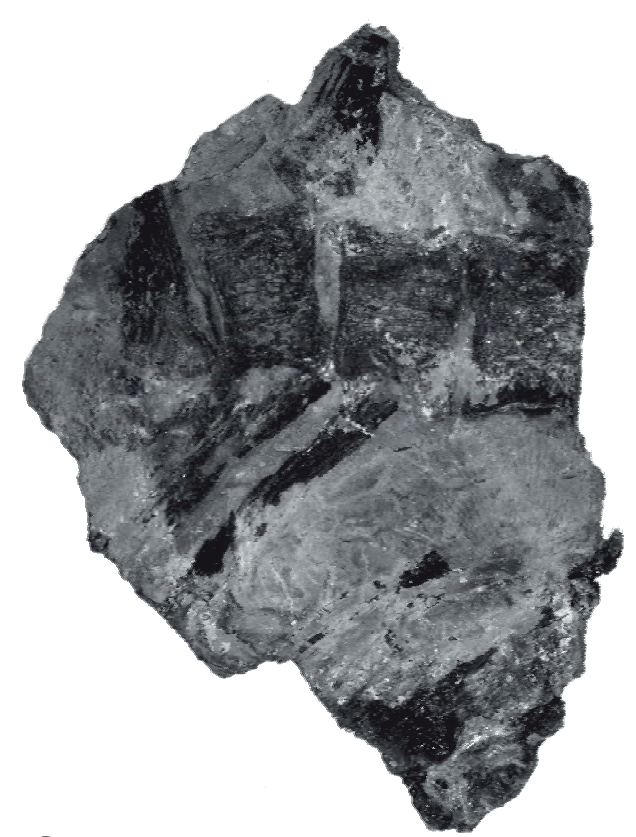

C

\section{$50 \mathrm{~mm}$}

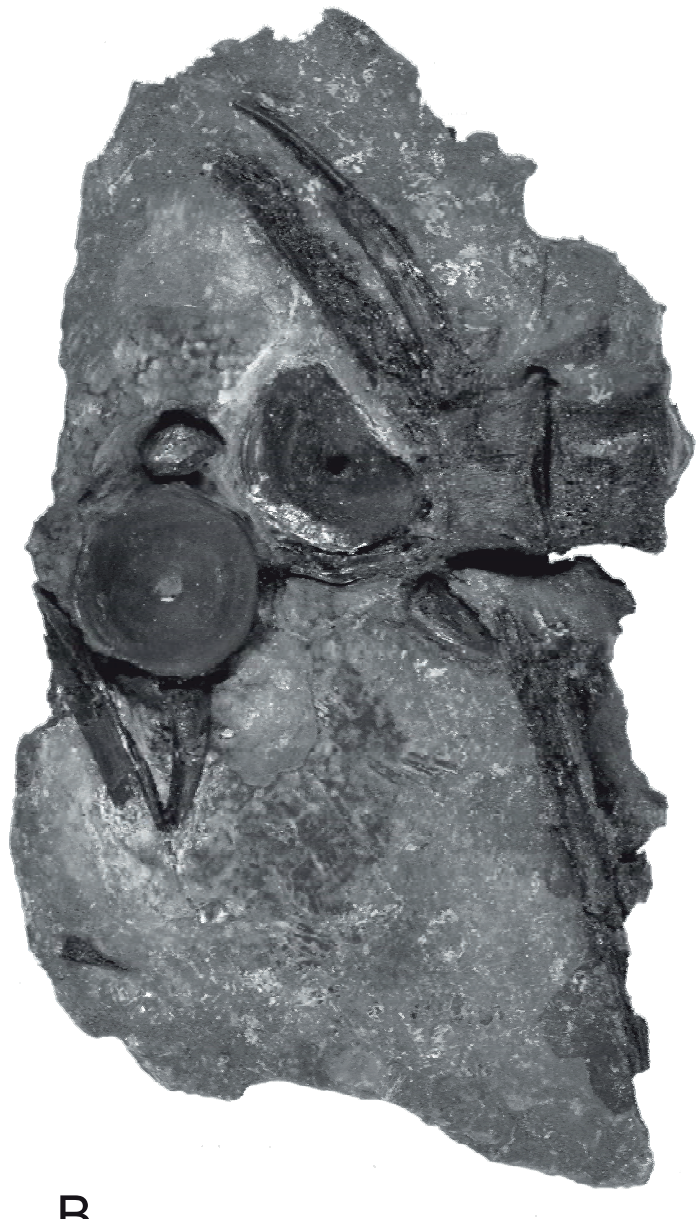

B

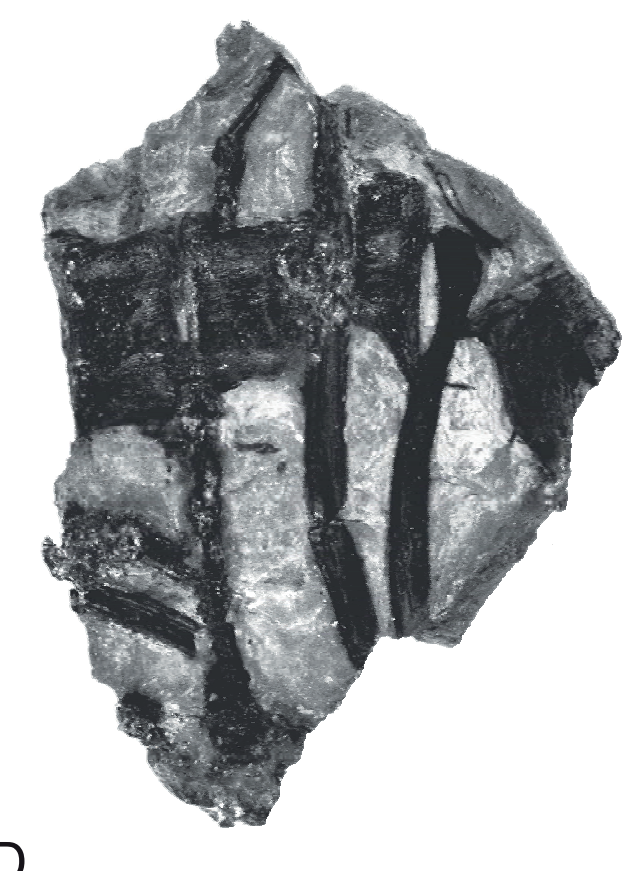

Figure 11. (A) Slab 3, with centra, neural spines, phalanges and rib elements of PMO 210.122/04. (B) Other side of slab 3, with centra and rib elements of PMO 210.122/04. (C) Slab 4, with centra, neural spines and rib elements of PMO 210.122/05. (D) Other side of slab 4, with centra and rib elements of PMO 210.122/05. 
Table 5. Selected appendicular element measurements of PMO 210.122 .

\begin{tabular}{lc}
\hline Selected appendicular element measurements & $\mathrm{mm}$ \\
\hline Coracoid facet of scapula & 9.4 \\
Glenoid facet of scapula & 17.0 \\
Scapular axis (anterior margin to posterior margin) & 112.1 \\
Scapular facet of coracoid & 12.1 \\
Glenoid facet of coracoid & 12.2 \\
Anteroproximal extension of coracoid & 55.4 \\
Diameter of rounded end of clavicle & 5.3 \\
\hline
\end{tabular}

10 in von Huene, 1916), although a coracoid facet on the scapula was scored as absent for Phalarodon in the phylogenetic study of Ichthyopterygia by Ji et al. (2015).
The symmetrical fan shape and glenoid process of the scapula of PMO 210.122 is very similar to observed scapulae of among others P. callawayi (plate 4, text-fig. 5 in Schmitz et al., 2004), P. fraasi (plate 1 in Schmitz et al., 2004) and Mixosaurus panxianensis (fig. 5 in Jiang et al., 2006).

The coracoid is preserved on slab 1a (Fig. 9). The surface of the glenoid process is broken off, and the missing part is preserved on slab 2 (Fig. 8). The surface of the posterior elongation is heavily damaged, but the outline of the posterior margin is still intact. The coracoid is an asymmetrical, axe-shaped element, fanning out from the glenoid process, similar to Phalarodon fraasi (plate 1 in Schmitz et al., 2004) and Mixosaurus panxianensis (fig. 4.5 in Jiang et al., 2006). The parasagittal length of the coracoid is greater than its transverse width. The medial margin of the coracoid is rounded, making the intercoracoid facet short. The anterior extension curves and forms a concavity with the margin connecting with
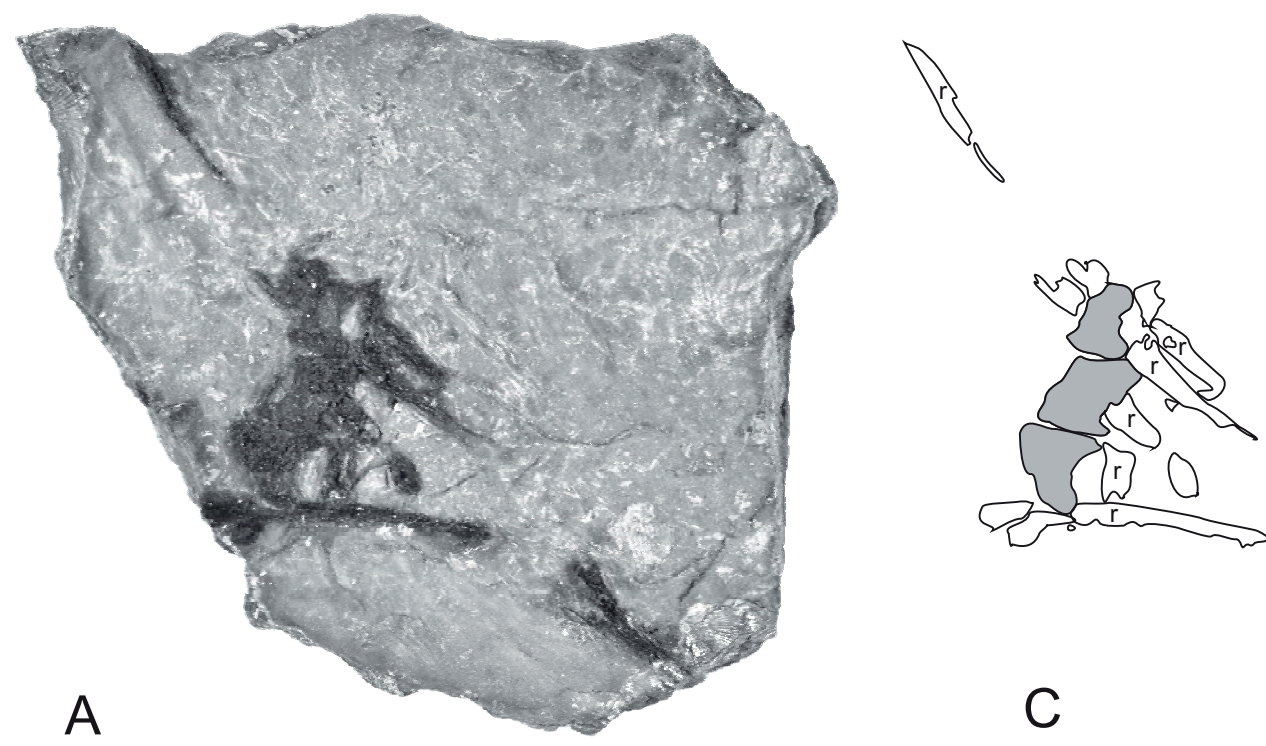

C
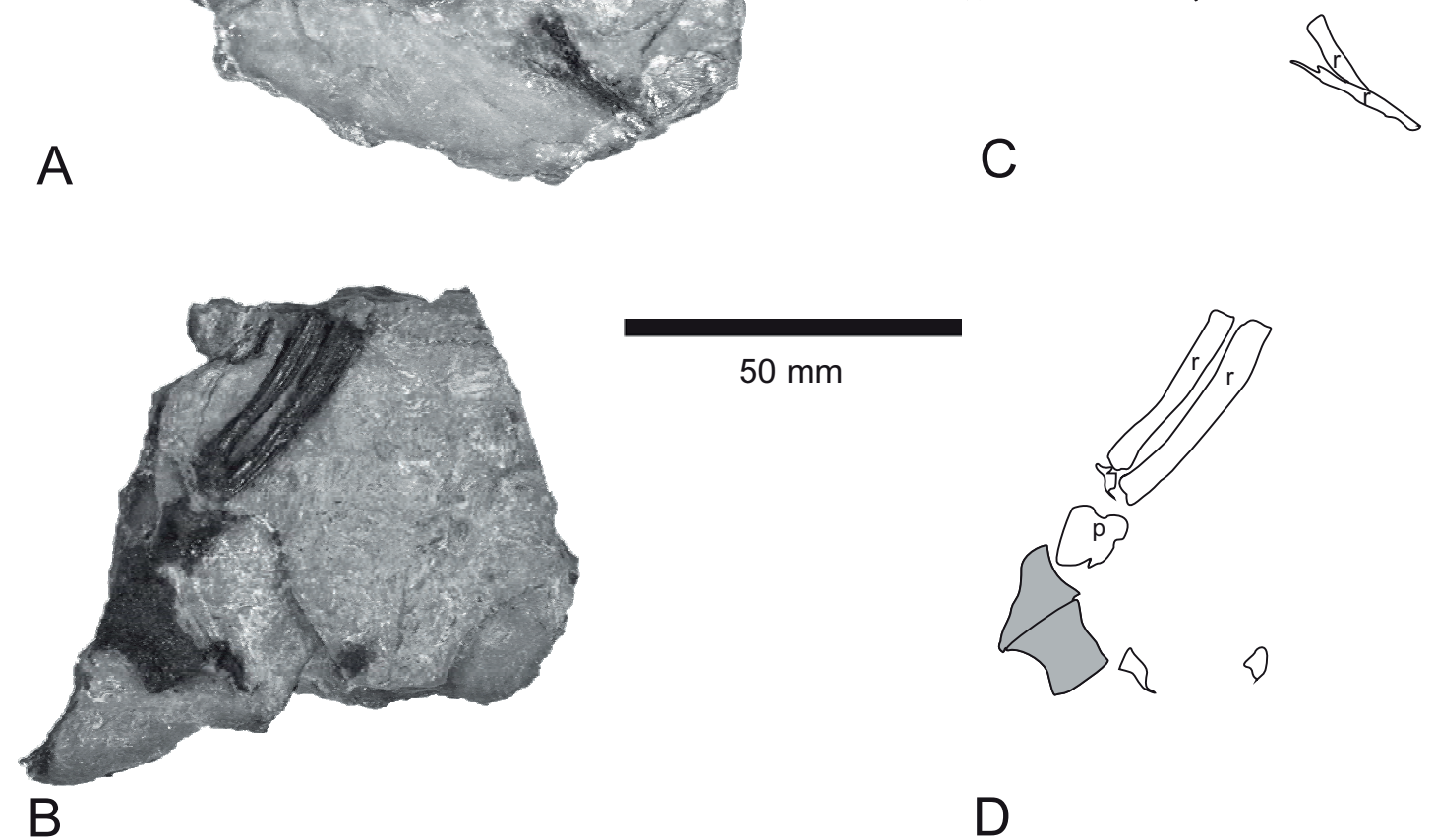

Figure 12. (A) Slab 7, with vertebra fragments and rib fragments of PMO 210.122/08. (B) Slab 6, with vertebra fragments, rib elements and one phalange element of PMO 210.122/07. (C) Interpretive drawing of elements on slab 7 (PMO 210.122/08), with vertebra remains in grey. (D) Interpretive drawing of elements on slab 6 (PMO 210.122/07), with vertebra remains in grey. Abbreviations: $p-p h a l a n g e, r-r i b$. 

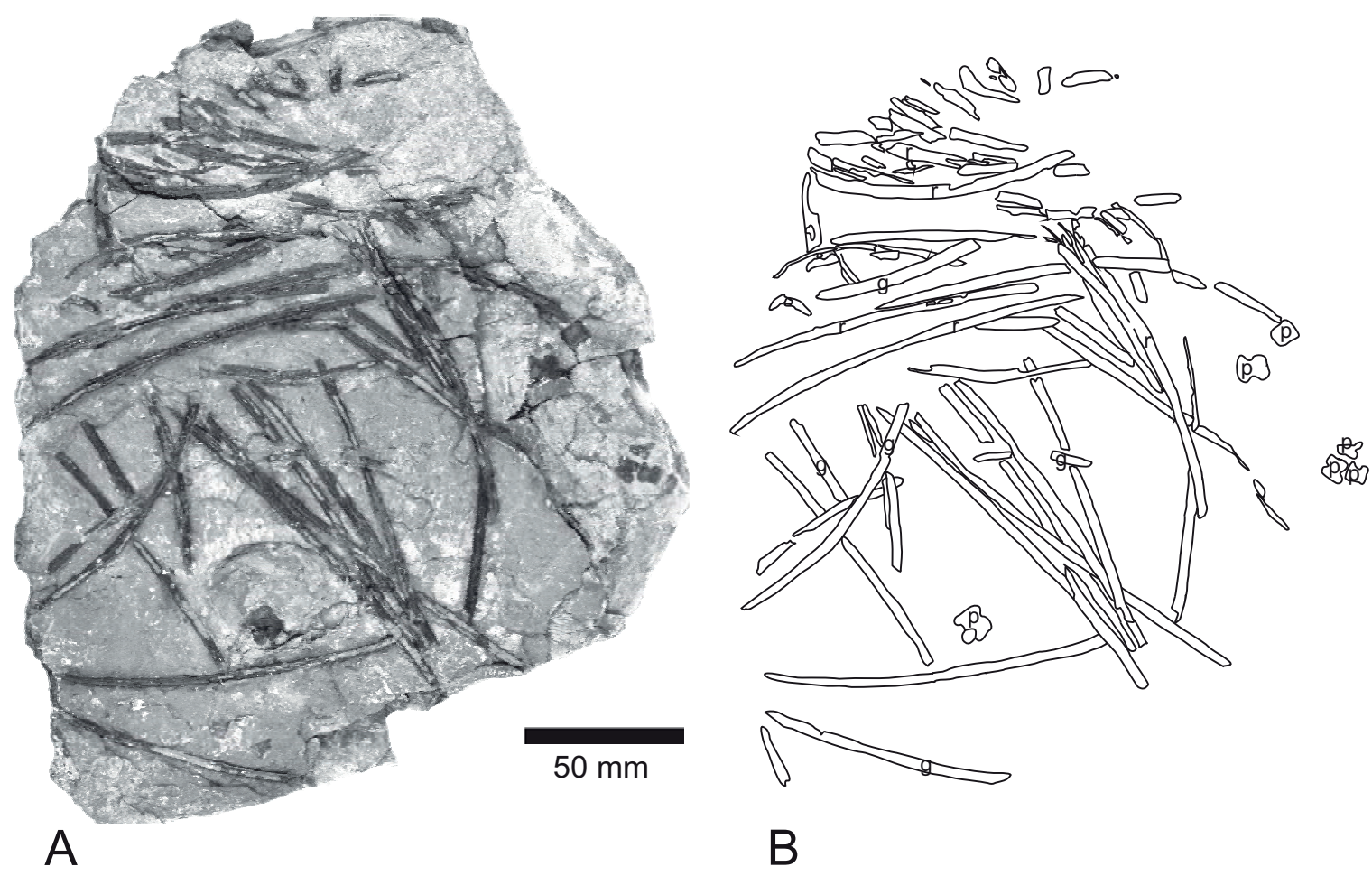

Figure 13. (A) Slab 5, with ribs, gastralia and phalange elements of PMO 210.122/06. (B) Interpretive drawing. Abbreviations: $g$ - gastralia, $p$-phalange, $r$-rib.

the glenoid process anteriorly. A gentler concave margin is also present posteriorly in the transition between the short posterior extension and the glenoid process. The glenoid process has two articular facets; one for the scapula, which is slightly longer, and the other for the humerus. The scapular articular facet is straight, while the glenoid facet is slightly concave. Fine surface striations are radiating out from the glenoid process.

The interclavicle is wholly exposed in posterodorsal view and partially exposed in anteroventral view (Figs. 8 \& 14). The transverse processes of the interclavicle are broken off, but they continue on slab 1a, exposed in ventral view (Fig. 9). The left transverse process is preserved as

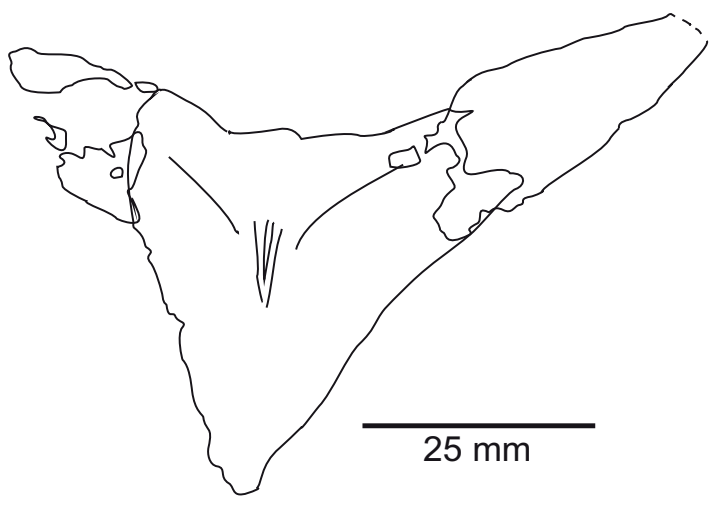

Figure 14. Reconstruction of the interclavicle of PMO 210.122, in which the remains from slab $1 a$ and 2 are combined. an impression and bone fragments. The anterodorsal margin of the interclavicle is a thick, rounded rim, from which the interclavicle extends posteriorly in a triangular process. The posterodorsal side is strongly concave, and the anteroventral side is equivalently strongly convex. The anterodorsal rim folds into and terminates at a point in the centrum of the posterior surface. Two small processes extend medially from the anterodorsal rim to a point posterior to the centrum of the dorsal surface. They are $1.7 \mathrm{~mm}$ apart at their anterior edge, and join together at their posterior end. The left lateral margin is damaged and incomplete. The right transverse process is thick and robust. It narrows distally, but the distal end is covered by a rib and matrix. The interclavicles of a specimen of Phalarodon fraasi from Svalbard (PMU 24561 pers. obs. I.H. Økland; Schmitz et al., 2004) were observed to have a transverse bar and triangular posterior process, similar to PMO 210.122. Details of the posterodorsal surface were not discernible, due to preservation or the element being exposed only in anteroventral view. The anteroventral surface of the interclavicle of PMU 24561 is convex, very similar to PMO 210.122. A specimen of Mixosaurus cornalianus (PMU 23652, plate 11: 1 in Wiman, 1912) has a well preserved interclavicle in which the external margins are retained. The transverse bar is thick anteromedially, and gets thinner laterally, while there is a wedge-like notch at the centrum of the anterior margin. Thus, the transverse bar extends like wings from the midline of the element. A small posterior process extends from the midline, the shape of which is triangular. The morphology consisting of a triangle, in 
which the transverse bar is broad and wing-like, is very similar to the interclavicle of M. kuhnschnyderi, although the posterior process is more robust and blunt in this species (fig. 13 in Brinkmann, 1998b). The holotype of $M$. panxianensis is preserved with the interclavicle, described as "broadly T-shaped, with its posterior process being about as long as its transverse bar whose distal parts are slightly projected anteriorly" (Jiang et al., 2006, p. 64). Apart from minor differences in shape and robustness, the transverse bar and triangular posterior process of the interclavicle appears to be a synapomorphy in mixosaurids.

The clavicle is a slender, long element of which only the middle section of the element is preserved (Fig. 8). The position of the clavicle relative to the interclavicle is nearly identical to how it was illustrated in the reconstruction of a shoulder girdle by von Huene (1916, fig. 10). At the lateral breakage point the element is completely rounded medially in cross-section. The medial breakage point is more heavily damaged and covered in matrix, but appears to flatten out to become rectangular in cross-section posterolaterally. Other features are not discernible due to preservation.

Limb elements - One single element is tentatively identified as an intermedium, due to its large size relative to other limb elements, and a distinctive notch (Fig. 8; Maisch \& Matzke, 1998; Motani, 1999b; Jiang et al., 2006). It seems to have had a hexagonal outline, but this is uncertain due to preservation. The shape of the element, including the notch, is very similar to the intermedium of an undescribed mixosaurid specimen PMU R493 (pers. obs. I.H. Økland). PMU R493 has a notch at the junction between the proximal margins, and seven facets are clearly present. A notch is also present on the proximal margin of the intermedium of Mixosaurus panxianensis (fig. 5 in Jiang et al., 2006), M. cornalianus (fig. 5 in Maisch \& Matzke, 1998; fig. 5d in Motani, 1999b) and P. fraasi (fig. 5g in Motani, 1999b). One element, which is preserved split between slabs 1a and 2 (Figs. 8 \& 10), is tentatively identified as a distal carpal. It is distinctly smaller than the intermedium, and the morphology is different from the phalanges. The outline is diamond shaped with five straight margins, out of which four are of approximately the same length. The last margin is distinctly shorter. In total 16 phalanges are preserved (Figs. 8, 10, 11, 12 \& 13). All these are disarticulated, and further identification was not possible. All preserved phalanges have a square morphology, with four straight margins, of which most are notched. Notching can occur on only one margin, both anterior and posterior margins or on none of them. Both anterior and posterior notchings give the phalanges an hourglass shape. In the phalanges in which only one margin is notched, the other side is either straight or with a slight indentation. One element has four straight margins, with no indication of notches. Similar phalangeal elements are observed in Phalarodon fraasi (PMU 24555 in Schmitz et al., 2004; fig. 5f, g in Motani, 1999b) and Mixosaurus cornalianus (fig. 5 in Maisch \& Matzke, 1998; fig. 5d, e in Motani, 1999b).

\section{Discussion}

Phylogenetic analyses - The results from the phylogenetic analyses of Ji et al. (2015) could not be exactly replicated. This could be a result of different settings in TNT. Additionally, this study used a different version of the program than was used in the original study. The phylogenetic trees had some slight changes in tree topology and were resolved further, as a result of fewer retained MPTs (see Electronic Supplement 1 and Table 6).

The tree topology is the same in the second analysis to that of the first analysis, second run, with the inclusion of PMO 210.122 and PMO 219.250. PMO 219.250 is positioned as a sister taxon within the unresolved ingroup of Mixosaurus. PMO 210.122 is placed as a sister taxon to $P$. fraasi and $P$. callawayi, in which their ingroup phylogeny is unresolved. P. atavus is situated as a sister taxon to the other two Phalarodon species and PMO 210.122.

PMO 210.122 - PMO 210.122 is assigned to the genus Phalarodon based on these synapomorphies (Ji et al., 2015): A dental labial shelf is present; teeth have

Table 6. Results of phylogenetic analyses.

\begin{tabular}{lccccc}
\hline & $\begin{array}{c}\text { First analysis, } \\
\text { first run }\end{array}$ & $\begin{array}{c}\text { Ji et al. (2015), } \\
\text { first run }\end{array}$ & $\begin{array}{c}\text { First analysis, } \\
\text { second run }\end{array}$ & $\begin{array}{c}\text { Ji et al. (2015), } \\
\text { second run }\end{array}$ & $\begin{array}{c}\text { Second } \\
\text { analysis. }\end{array}$ \\
\hline MPT & 23 & 247 & 17 & 84 & 19 \\
Steps & 538 & 538 & 501 & 501 & 506 \\
{$[\mathrm{CI}]$} & 0.375 & 0.3741 & 0.401 & 0.4012 & 0.397 \\
{$[\mathrm{RI}]$} & 0.778 & 0.7776 & 0.786 & 0.7862 & 0.787 \\
Bremer support of Mixosauridae clade & 5 & 5 & 5 & 5 & 2 \\
\hline
\end{tabular}




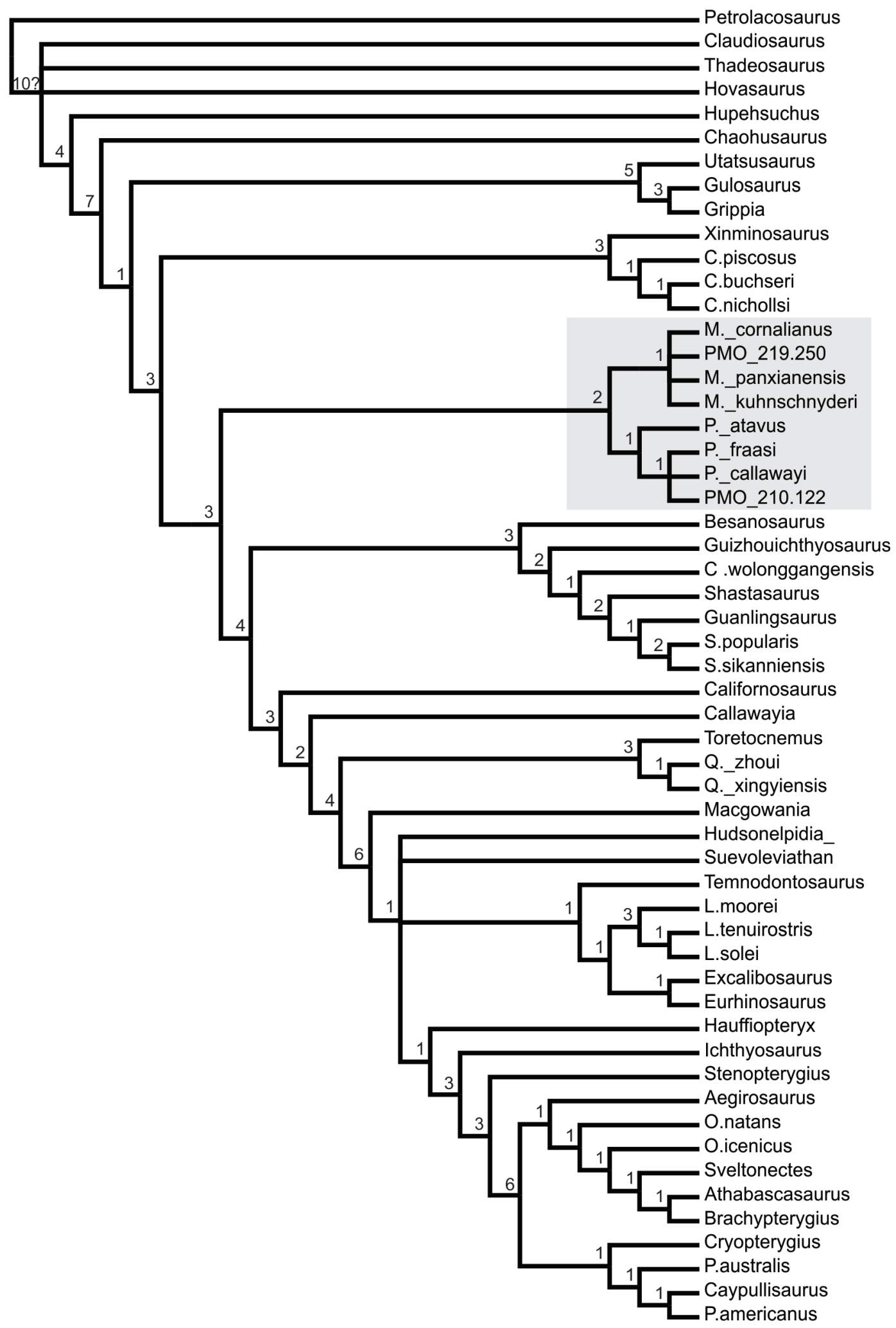

Figure 15. Strict consensus tree with Bremer support values to the upper left of each corresponding node, found by TNT in the second analysis. Phylogenetic assignment of PMO 210.122 and PMO 219.250. Grey background: Mixosauridae.

Genus names abbreviated. C.piscosus, C.buchseri, C.nichollsi - Cymbospondylus; C. wolonggangensis - Callawayia; L.moorei, L.tenuirostris, L.solei - Leptopterygius; M._cornalianus, M._panxianensis, M._kuhnschnyderi - Mixosaurus; O.natans, O.icenicus Ophthalmosaurus; P._atavus, P._fraasi, P._callawayi - Phalarodon; P.australis, P.americanus - Platypterygius; Q._zhoui, Q._xingyiensis Qianichthyosaurus; S.popularis, S.sikanniensis - Shastasaurus. 
a laterally compressed horizontal section; the posterior tooth crown is flat in the single most posteriorly preserved tooth. The diagnosis of Phalarodon by Ji et al. (2015) separates the three species based on the horizontal section of the teeth and the shape of the posterior tooth crown. Phalarodon callawayi has teeth with circular cross-section, while Phalarodon atavus has conical posterior tooth crowns. According to these tooth features, PMO 210.122 is neither P. callawayi nor $P$. atavus. Several traits of PMO 210.122 were observed to be similar to P. callawayi, such as the sclerotic ring and the atlas-axis complex (Schmitz et al., 2004). The special morphology of the opisthotic is shared with Mixosaurus cf. cornalianus (Maisch et al., 2006), and might be present in all species within Mixosauridae. The same trait has been observed in Phantomosasaurus neubigi (Sander, 1997; Maisch \& Matzke, 2006), indicating that this might be a basal, nonparvipelvian trait (Marek et al., 2015). The presence of parapophyses on the cervical centra as observed in PMO 210.122 is also observed in Mixosaurus cornalianus, $M$. kuhnschnyderi and $P$. cf. fraasi (Brinkmann, 1998b), indicating that this is common in Mixosauridae. Other specimens of $P$. fraasi lack parapophyses on the cervical centra (Nicholls et al., 1999; Schmitz et al., 2004). This contradiction within $P$. fraasi might be due to preservation, or actual interspecific variation. Another trait; deep, amphicoelous centra each with a small perforation, as observed in P. atavus (Fraas, 1891), was also found in PMO 210.122. The intergeneric and interspecific variance of shape of the interclavicle within Mixosauridae has been scarcely studied, although Wiman (1910) and Brinkmann (1998b) briefly compared this element at the interspecific level. Although the interclavicle of PMO 210.122 is similar to that of Phalarodon fraasi, this trait could very well be shared within the genus. PMO 210.122 shares many features with $P$. fraasi, in terms of morphology. The rostrum has slender, conical teeth anteriorly, while posterior teeth are mesiodistally elongated, with a mesiodistal ridge (Motani, 2005). The shape and placement of facets of the anterior dorsal centra are similar (Nicholls et al., 1999; Schmitz et al., 2004). The shape of the interclavicle, with a transverse bar and triangular posterior process (Wiman, 1910) as well as intermedium with a proximal notch and phalanges with anterior and posterior notches (Motani, $1999 b$ ) are shared traits. From the observations of the anatomy of PMO 210.122 and the diagnostic features of Phalarodon, the specimen should be assigned to Phalarodon fraasi. The phylogenetic analyses supports the assignment of PMO 210.122 within Phalarodon, and establishes an affinity towards the sister taxa $P$. callaway $i$ and $P$. fraasi (Fig. 15). As PMO 210.122 shares features with both species, and all characters were weighted equally, this result is expected. However, as the differences between $P$. callawayi and $P$. fraasi are few and subtle (Schmitz et al., 2004; Maxwell \& Kear, 2013), several postcranial features known in $P$. callawayi are unknown in $P$. fraasi, and might prove to be shared between the two species, such as the morphology of the atlas-axis complex. Tooth attachment displays variance within the Ichthyopterygia, and also great interspecific variation within the six acknowledged species of mixosaurids (Motani, 1997; Maxwell et al., 2011); thus, the difference in the alveolar bone spanning the dental groove may be explained by ontogeny. The scapula, when present, is either fragmentarily preserved or incomplete (Nicholls et al., 1999; Jiang et al., 2005; Hurum et al., 2014). Based on previously described material, Ji et al. (2015) scored the coracoid facet of scapula to be absent within the species of Mixosauridae, as might be the case for Mixosaurus panxianensis (Jiang et al., 2006). The scapula of PMO 210.122 is well preserved in articulation with the coracoid, revealing the presence of a second facet on the scapular glenoid process, supported by the observation of the same structure in $P$. atavus (von Huene, 1916). As the shape of the scapula is shared within the Mixosauridae (McGowan \& Motani, 2003; Schmitz et al., 2004; Jiang et al., 2006), the presence of a coracoid facet on the scapula is probably a shared trait.

PMO 219.250 - The description of PMO 219.250 was inconclusive as the specimen shares features with all known species of Mixosauridae (Hurum et al., 2014), although the narial region was observed to have a pronounced narial shelf, a synapomorphy of Phalarodon (Ji et al., 2015). The phylogenetic analyses support PMO 219.250 being Mixosaurus sp. (Fig. 15). This result is the first indication of Mixosaurus on Svalbard, as the previously described mixosaurids from Svalbard belong to Phalarodon (Maxwell \& Kear, 2013).

\section{Conclusions}

The phylogenetic analyses, although not able to give full confirmation to the species affinity for either PMO 210.122 or PMO 219.250, still support the results of the comparative anatomy. Both specimens are firmly placed within the Mixosauridae in the analysis. The split into two clades representing Mixosaurus and Phalarodon was obtained (Fig. 15), and it is the same as in previous studies (Maisch \& Matzke, 2001a; Jiang et al., 2006; Ji et al., 2015), as expected.

From anatomy, diagnostic features and phylogenetic analyses, it is concluded that PMO 210.122 should be referred to Phalarodon fraasi. Although PMO 210.122 is one of many specimens of Phalarodon retrieved from Svalbard, it is significant as being perhaps the best preserved among them. This specimen provides important information about the morphology of the rostrum, interclavicle, atlas-axis complex, opisthotic and the articulation of scapula to the coracoid. PMO 219.250 possibly confirms the presence of Mixosaurus on Svalbard, but more fieldwork, providing more complete and articulated specimens, is needed to fill the gaps in 
our anatomical knowledge, and sort out the phylogeny of the species and genera of Mixosauridae.

Acknowledgements. Thanks to PMU and Benjamin Kear for inviting NHM-students to look at their collection. Thanks to the late Prof. Wolfgang Weitschat for collecting PMO 210.122 and for stratigraphic placement. Thanks to Spitsbergen travel, National Geographic, Bayerngas Norge, Tullow Oil and CGG for financing fieldwork. A special thanks to Frank Osbeck for extensive preparation guidance. Thanks to Bjørn Lund, May-Liss Funke and Hanne Daae Quale (2006, Konservatorskolen. Det Kongelige Danske Kunstakademi), for help and guidance with preparation of the material. Thanks to Martin Sander and Patrick Druckenmiller for valuable guidance concerning the phylogenetic analyses. Thanks to Øyvind Hammer and Hans Arne Nakrem, for great help with the $\mu$-CT scan and illustrations. Thanks to the reviewers Benjamin Kear and Erin Maxwell for a lot of constructive criticism.

\section{References}

Baur, G. 1887: On the morphology and origin of Ichthyopterygia. American Naturalist 21,837-840.

Blainville, H.M.D.d. 1835: Description de quelques espèces de reptiles de la Californie: précédée de l'analyse d'un systéme général d'erpétologie et d'amphibiologie. Nouvelles Annales du Muséum d'Histoire Naturelle 4, 233-296.

Brinkmann, W. 1998a: Sangiorgiosaurus n.g. - eine neue MixosaurierGattung (Mixosauridae, Ichthyosauria) mit Quetschzähnen aus der Grenzbitumenzone (Mitteltrias) des Monte San Giorgio (Schweiz, Kanton Tessin). Neues Jahrbuch für Geologie und Paläontologie Abhandlungen 207, 125-144.

Brinkmann, W. 1998b: Die Ichthyosaurier (Reptilia) aus der Grenzbitumenzone (Mitteltrias) des Monte San Giorgio (Tessin, Schweiz) - neue Ergebnisse. Vierteljahresschrift der Naturforschenden Gesellschaft Zürich 143, 165-177.

Brinkmann, W. 2004: Mixosaurier (Reptilia, Ichthyosauria) mit Quetschzähnen aus der (Mitteltrias) des Monte San Giorgio (Schweiz, Kanton Tessin). Schweizerische Paläontologische Abhandlungen 124, 1-86.

Buchan, S.H., Challinor, A., Harland, W.B. \& Parker, J.R. 1965: The Triassic stratigraphy of Svalbard. Norsk Polarinstitutt Skrifter 135, 1-92.

Callaway, J.M. 1997: A new look at Mixosaurus. In Callaway, J.M. \& Nicholls, E.L. (eds): Ancient Marine Reptiles, Academic Press, San Diego, 45-59. https://doi.org/10.1016/B978-012155210-7/50005-3.

Callaway, J.M. \& Brinkman, D.R. 1989: Ichthyosaurs (Reptilia, Ichthyosauria) from the Lower and Middle Triassic Sulphur Mountain Formation, Wapti Lake area, British Columbia. Canadian Journal of Earth Sciences 26, 1491-1500. https://doi.org/10.1139/e89-126.

Cox, C.B. \& Smith, D.G. 1973: A review of the Triassic vertebrate faunas of Svalbard. Geological Magazine 110, 405-418. https://doi.org/10.1017/S0016756800036190.

Dallmann, W.K. 2015: Geoscience Atlas of Svalbard. Norsk Polarinstitutt Report Series 148, Norwegian Polar Institute, Tromsø, 292 pp.

Dames, W. 1895: Über die Ichthyopterygier der Triasformation. Sitzungsberichte der Königlich Preussichen Akademie der Wissenschaften zu Berlin 46, 1045-1050.

Fraas, E. 1891: Die Ichthyosaurier der süddeutschen Trias- und JuraAblagerungen. Verlag der H. Laupp'schen Buchhandlung, Tübingen, $81 \mathrm{pp}$.
Goloboff, P.A., Farris, J.S. \& Nixon, K.C. 2008: TNT, a free program for phylogenetic analysis. Cladistics 24, 774-786. https://doi. org/10.1111/j.1096-0031.2008.00217.x.

Hounslow, M.W., Hu, M., Mørk, A., Weitschat, W., Vigran, J.O., Karloukovski, V. \& Orchard, M.J. 2008: Intercalibration of boreal and Tethyan times scales: the magnetosbiostratigraphy of the Middle Triassic and the latest Early Triassic from Spitsbergen, Artic Norway. Polar Research 27, 469-490. https://doi.org/10.1111/j.1751-8369.2008.00074.x.

Hulke, J.W. 1873: Memorandum on some fossil vertebrate remains collected by the Swedish expedition to Spitzbergen in 1864 and 1868. Bihang till Kungliga Svenska Vetenskapsakademiens Handlingar 1, Afdelning IV, 9, 1-11.

Hurum, J.H., Roberts, A.J., Nakrem, H.A., Stenløkk, J.A. \& Mørk, A. 2014: The first recovered ichthyosaur from the Middle Triassic of Edgeøya, Svalbard. Norwegian Petroleum Directorate Bulletin 11, 97-110.

Ji, C., Jiang, D.-Y., Motani, R., Rieppel, O., Hao, W.-C. \& Sun, Z.-Y. 2015: Phylogeny of the Ichthyopterygia incorporating recent discoveries from South China. Journal of Vertebrate Paleontology 36, e1025956. https://doi.org/10.1080/02724634.2015.1025956.

Jiang, D.-Y., Hao, W.-C., Sun, Y.-L., Maisch, M.W. \& Matzke, A.T. 2003: The mixosaurid ichthyosaur Phalarodon from the Middle Triassic of China. Neues Jahrbuch für Geologie und Paläontologie, Monatshefte 2003, 656-666.

Jiang, D.-Y., Hao, W.-C., Maisch, M.W., Matzke, A.T. \& Sun, Y.-L. 2005: A basal mixosaurid ichthyosaur from the Middle Triassic of China. Palaeontology 48, 869-882. https://doi.org/10.1111/j.1475-4983.2005.00481.x.

Jiang, D.-Y., Schmitz, L., Hao, W.-C. \& Sun, Y.-L. 2006: A new mixosaurid ichthyosaur from the Middle Triassic of China. Journal of Vertebrate Paleontology 26, 60-69. https://doi.org/10.1671/0272-4634(2006)26[60:ANMIFT]2.0.CO;2.

Jiang, D.-Y., Schmitz, L., Motani, R., Hao, W.-C. \& Sun, Y.-L. 2007: The mixosaurid ichthyosaur Phalarodon cf. P. fraasi from the Middle Triassic of Guizhou Province, China. Journal of Paleontology 81, 602-605. https://doi.org/10.1666/05092.1.

Jiang, D.-Y., Motani, R., Hao, W.-C., Schmitz, L., Rieppel, O., Sun, Y. \& Sun, Z. 2008: New primitive ichthyosaurian (Reptilia, Diapsida) from the Middle Triassic of Panxian (Guizhou, southwestern China) and its position in the Triassic Biotic Recovery. Progress in Natural Science 18, 1315-1319. https://doi.org/10.1016/j.pnsc.2008.01.039.

Kelley, N.P., Motani, R., Jiang, D.-Y., Rieppel, O. \& Schmitz, L. 2012: Selective extinction of Triassic marine reptiles during long-term sea-level changes illuminated by seawater strontium isotopes. Palaeogeography, Palaeoclimatology, Palaeoecology 400, 9-16. https://doi.org/10.1016/j.palaeo.2012.07.026.

Krajewski, K.P. 2008: The Botneheia Formation (Middle Triassic) in Edgeøya and Barentsøya, Svalbard: lithostratigraphy, facies, phosphogenesis, paleoenvironment. Polish Polar Research 29, 319-364.

Kuhn, O. 1934: Ichthyosauria.In Quenstedt W. (ed): Fossilium Catalogus. 1, Animalia, pars, 63, W. Junk, Berlin, 75 pp.

LeBlanc, A.R.H., Brink, K.S., Cullen, T.M. \& Reisz, R.R. 2017. Evolutionary implications of tooth attachment versus tooth implantation: a case study using dinosaur, crocodilian, and mammal teeth. Journal of Vertebrate Paleontology 37, e1354006. https://doi.org/10.1080/02724634.2017.1354006.

Liu, J., Motani, R., Jiang, D.-Y., Hu, S.-X., Artchison, J.C., Rieppel, O., Benton, M.J., Zhang, Q.-Y. \& Zhou, C.-Y. 2013: The first specimen of the Middle Triassic Phalarodon atavus (Ichthyosauria: Mixosauridae) from South China, showing postcranial anatomy and peri-Tethyan distribution. Palaeontology 56, 849-866. https://doi.org/10.1111/pala.12021.

Lundschien, B.A., Høy, T. \& Mørk, A. 2014: Triassic Hydrocarbon Potential in the Northern Barents Sea; integrating Svalbard and stratigraphic core data. Norwegian Petroleum Directorate Bulletin 11, 3-20. 
Maddison, W.P. \& Maddison, D.R. 2015: Mesquite: a modular system for evolutionary analysis, version 3.04. http://mesquiteproject.org.

Maisch, M.W. \& Matzke, A.T. 1997: Observations on Triassic ichthyosaurs. Part I: Structure of the palate and mode of tooth implantation in Mixosaurus cornalianus (Bassani, 1886). Neues Jahrbuch für Geologie und Paläontologie, Monatshefte 1997,717-732.

Maisch, M.W. \& Matzke, A.T. 1998: Observations on Triassic ichthyosaurs. Part IV. On the forelimb of Mixosaurus Baur, 1887. Neues Jahrbuch für Geologie und Paläontologie, Abhandlungen 209, 247-272.

Maisch, M.W. \& Matzke, A.T. 2000: The Ichthyosauria. Stuttgarter Beiträge zur Naturkunde Serie B (Geologie und Paläontologie) 298, $1-159$.

Maisch, M.W. \& Matzke, A.T. 2001a: Observations on Triassic ichthyosaurs. Part VIII. A redescription of Phalarodon major (von Huene, 1916) and the composition and phylogeny of the Mixosauridae. Neues Jahrbuch für Geologie und Paläontologie, Abhandlungen 220, 431-447. https://doi.org/10.1127/njgpa/220/2001/431.

Maisch, M.W. \& Matzke, A.T.2001b: The cranial osteology of the Middle Triassic ichthyosaur Contectopalatus from Germany. Palaeontology 44,1127-1156. https://doi.org/10.1111/1475-4983.00218.

Maisch, M.W. \& Matzke, A.T. 2006: The braincase of Phantomosaurus neubigi (Sander 1997), an unusual ichthyosaur from the Middle Triassic of Germany. Journal of Vertebrate Paleontology 26, 598-607. https://doi.org/10.1671/0272-4634(2006)26[598:TBOPNS]2.0.CO;2.

Maisch, M.W., Matzke, A.T. \& Brinkmann, W. 2006: The otic capsule of the Middle Triassic ichthyosaur Mixosaurus from Monte San Giorgio (Switzerland): new evidence on the braincase structure of basal ichthyosaurs. Eclogae Geologiae Helveticae 99, 205-210. https://doi.org/10.1007/s00015-006-1189-6.

Marek, R.D., Moon, B.C., Williams, M. \& Benton, M.J. 2015: The skull and endocranium of a Lower Jurassic ichthyosaur based on digital reconstructions. Palaeontology 58, 723-742.

https://doi.org/10.1111/pala.12174.

Maxwell, E.E. \& Kear, B.P. 2013: Triassic ichthyopterygian assemblages of the Svalbard Archipelago: a reassessment of taxonomy and distribution. Geologiska Föreningen i Stockholm Förhandlingar 135, 85-94. https://doi.org/10.1080/11035897.2012.759145.

Maxwell, E.E., Caldwell, M.W. \& Lamoureux D.O. 2011: Tooth histology in the Cretaceous ichthyosaur Platypterygius australis, and its significance for the conservation and divergence of mineralized tooth tissues in amniotes. Journal of Morphology 272, 129-135. https://doi.org/10.1002/jmor.10898.

Mazin, J.-M. 1983: Répartition stratigraphique et géographique des Mixosauria (Ichthyopterygia). Provincialite marine au Trias moyen. In Buffetaut, E., Mazin, J.-M. \& Salmon, E. (eds): Actes du Symposium Paléontologique Georges Cuvier, 1982, Montbéliard, France, pp. 375-387.

Mazin, J.-M. 1984: Les Ichthyopterygia du Trias du Spitsberg. Descriptions complémentaires à partir d'un noveau matériel. Bulletin du Museum national d'Histoire naturelle, Paris 6, 309-320.

McGowan, C. \& Motani, R. 2003: Ichthyopterygia, Handbook of Paleoherpetology, Verlag Dr. Friedrich Pfeil, München, 175 pp.

Merriam, J.C. 1910: The skull and dentition of a primitive ichthyosaurian from the Middle Triassic. University of California Publications, Bulletin of the Department of Geology 5, 381-390.

Merriam, J.C. 1911: Notes on the relationships of the marine saurian fauna described from the Triassic of Spitzbergen by Wiman. University of California Publications, Bulletin of the Department of Geology 6, 317-327.

Moon, B.C. 2017. A new phylogeny of ichthyosaurs (Reptilia: Diapsida). Journal of Systematic Palaeontology. https://doi.org/10.1080/14772019.2017.1394922.
Motani, R. 1997: Temporal and spatial distribution of tooth implantation in ichthyosaurs. In Callaway, J.M. \& Nicholls, E.L. (eds): Ancient Marine Reptiles, Academic Press, San Diego, pp. 81-103. https://doi.org/10.1016/B978-012155210-7/50007-7.

Motani, R. 1999a: The skull and taxonomy of Mixosaurus (Ichthyopterygia). Journal of Paleontology 73, 924-935. https://doi.org/10.1017/S0022336000040750.

Motani, R. 1999b: On the evolution and homologies of ichthyopterygian forefins. Journal of Vertebrate Paleontology 19, 28-41. https://doi.org/10.1080/02724634.1999.10011120.

Motani, R. 2005: Detailed tooth morphology in a durophagous ichthyosaur captured by 3D laser scanner. Journal of Vertebrate Paleontology 25, 462-465. https://doi.org/10.1671/0272-4634(2005)025[0462:DTMIAD]2.0.CO;2.

Mørk, A., Knarud, R. \& Worsley, D. 1982: Depositional and diagenetic environments of the Triassic and Lower Jurassic succession of Svalbard. In Embry, A.F. \& Balkwill, H.R. (eds): Arctic Geology and Geophysics, Canadian Society of Petroleum Geologists Memoir 8, pp. 371-398.

Mørk, A., Elvebakk, G., Forsberg, A.W., Hounslow, M.W., Nakrem, H.A., Vigran, J.O. \& Weitschat, W. 1999: The type section of the Vikinghøgda Formation: a new Lower Triassic unit in central and eastern Svalbard. Polar Research 18, 51-82. https://doi.org/10.3402/polar.v18i1.6558.

Nicholls, E.L., Brinkman, D.B. \& Callaway, J.M. 1999: New material of Phalarodon (Reptilia: Ichthyosauria) from the Triassic of British Columbia and its bearing on the interrelationships of mixosaurs. Palaeontographica Abteilung A 252, 1-22.

Owen, R. 1840: Report on British fossil reptiles. Part I. Report of the British Association for the Advancement of Science 9, 43-96.

Sander, P.M. 1997: The paleobiogeography of Shastasaurus. In Callaway, J.M. \& Nicholls, E.L. (eds): Ancient Marine Reptiles, Academic Press, San Diego, pp. 17-43. https://doi.org/10.1016/B978-012155210-7/50004-1.

Sander, P.M. \& Bucher, H. 1990: On the presence of Mixosaurus (Ichthyopterygia: Reptilia) in the Middle Triassic of Nevada. Journal of Paleontology 64, 161-164. https://doi.org/10.1017/S0022336000042396.

Schmitz, L. 2005: The taxonomic status of Mixosaurus nordenskioeldii (Ichthyosauria). Journal of Vertebrate Paleontology 25, 983-985. https://doi.org/10.1671/0272-4634(2005)025[0983:TTSOMN]2.0.CO;2.

Schmitz, L., Sander, P.M., Storrs, G.W. \& Rieppel, O. 2004: New Mixosauridae (Ichthyosauria) from the Middle Triassic of the Augusta Mountains (Nevada, USA) and their implications for mixosaur taxonomy. Palaeontographica Abteilung A 270, 133-162.

Stensiö, E.A. 1921: Triassic fishes from Spitzbergen, Part I. Vienna, 307 pp.

Vigran, J.O., Mangerud, G., Mørk, A., Worsley, D. \& Hochuli, P.A. 2014: Palynology and geology of the Triassic succession of Svalbard and the Barents Sea. Geological Survey of Norway Special Publication 14, $1-270$.

von Huene, F. 1916: Beiträge zur Kenntnis der Ichthyosaurier im deutschen Muschelkalk. Palaeontographica 62, 1-68.

Weitschat, W. \& Lehmann, U. 1983: Stratigraphy and ammonoids from the Middle Triassic Botneheia Formation (Daonella Shales) of Spitsbergen. Mitteilungen aus dem Geologisch-Palaöntologischen Institut der Universität Hamburg 54, 27-54.

Wiman, C. 1910: Ichthyosaurier aus der Trias Spitzbergens. Bulletin of the Geological Institution of the University of Uppsala 10, 124-148.

Wiman, C. 1912: Über Mixosaurus cornalianus Bass. sp. Bulletin of the Geological Institution of the University of Uppsala 11, 230-241.

Wiman, C. 1916: Notes on the marine Triassic reptile fauna of Spitsbergen. University of California Publications, Bulletin of the Department of Geology 10, 63-73. 